\title{
Quiet Eye Changes under Environmental Constraints During Performance Target Launcher Skills
}

\author{
Amin Amini ${ }^{1}$, Shahzad Tahmasebi Boroujeni ${ }^{2}$, Elahe Arabameri ${ }^{3}$, Hasan Ashayeri ${ }^{4}$ \\ 1. Amin Amini, (Ph. D) Imam Hossein University, Tehran, Iran. \\ 2. Shahzad Tahmasebi Boroujeni, (Ph. D) University of Tehran, Tehran, Iran. \\ 3. Elahe Arabameri, (Ph. D) University of Tehran, Tehran, Iran. \\ 4. Hasan Ashayeri, (Ph. D) Iran University of Medical Sciences, Tehran, Iran.
}

\section{ARTICLE INFO}

Received June 2018

Accepted August 2018

\section{KEYWORDS:}

Gaze Behavior,

Regulatory Conditions, Inter-trial Variability, Gentile's 2-Dimensions.

\section{CITE:}

Amini, Tahmasebi Boroujeni, Arabameri, Ashayeri, Quiet Eye Changes under Environmental Constraints during Performance Target Launcher Skills, Research in Sport Management \& Motor Behavior, 2020: 10(20): 45-62

\section{ABSTRACT}

The ability to direct the gaze to optimal areas in the environmental context, at the appropriate time, is central to success in all sports. The aim of this study was to changes determine the elements of $\mathrm{QE}$, during the run a reactivity launcher targeting skill, under different environmental demands. That was done to identify perceptual - cognitive effects performance-based infrastructure processes. Thus, 8 Athletes (22-28 Years old) with at least 5 years' experience in dart throwing, in a counterbalanced manner performed under four target conditions of constraints environmental. Regulatory conditions (stationary/in motion) and inter-trial variability (present/absent) created four target conditions for reaction. During the run a launcher targeting skill and was continuously recorded characteristics related to gaze behavior in each scenario. In each condition, 10 trails 20 seconds conducted. Gaze behavior using an eye-tracking device Dikablis Professional Wireless model recorded and analyzed using DLab software information processing system and variance (ANOVA) with repeated measures. Results showed that there was significant between averages QE in four different environmental contexts $(P \leq 0.001)$. The fastest $Q E$ onset was observed stationary - no inter-trial variability and QE offset and QE period belonged to in motion - no inter-trial variability and in motion- inter-trial variability. In general investigating factors involved in skillful performance in different implementation conditions in response to various constraints can be facilitator and effective in identifying important factors learning motor skills. 


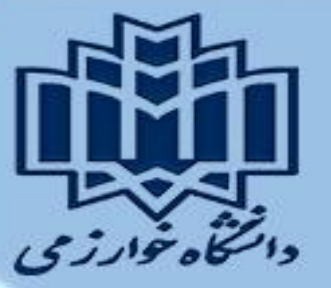

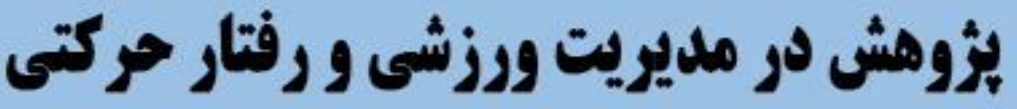

مقاله بُخوهشى

\section{تغيير ات جشم آرام تحت قيد محيط حين اجراى مهارت هدف تيرى يرتابى}

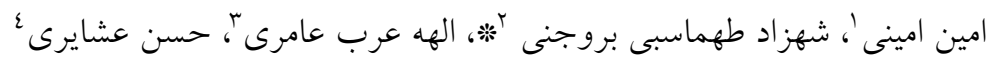

$$
\begin{aligned}
& \text { 1. استاديار يزوهشكده دانش و هوش شناختى، دانشكاه جامع امام حسين(ع)، تهران، ايران. } \\
& \text { r. دانشيار كروه رفتار حركتى و روانشناسى ورزشى، دانشكدة تربيت بدنى و علوم ورزشى، دانشعاه تهران، تهران، ايران. }
\end{aligned}
$$

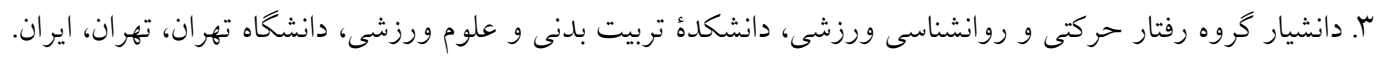

\begin{tabular}{|c|c|}
\hline 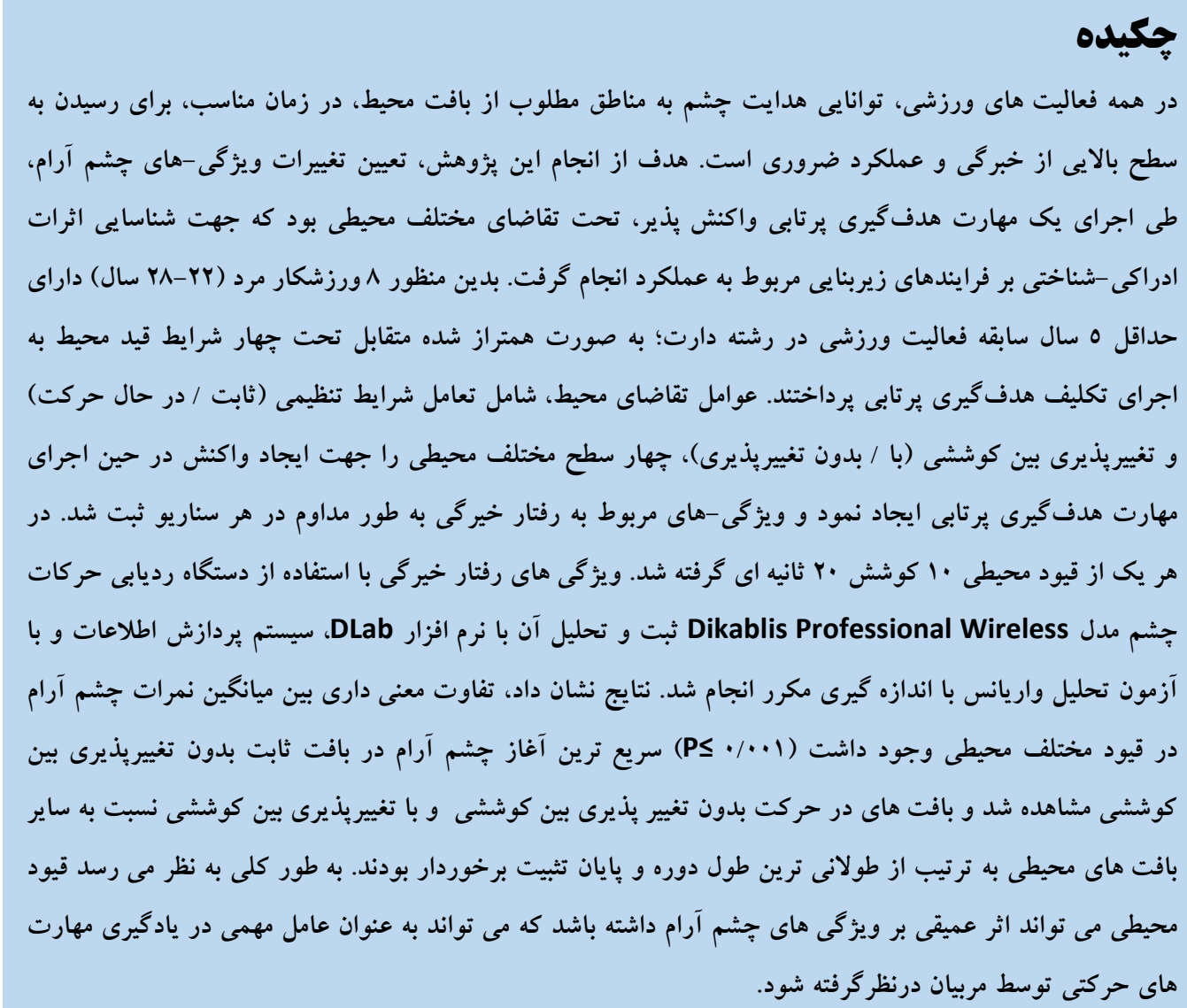 & 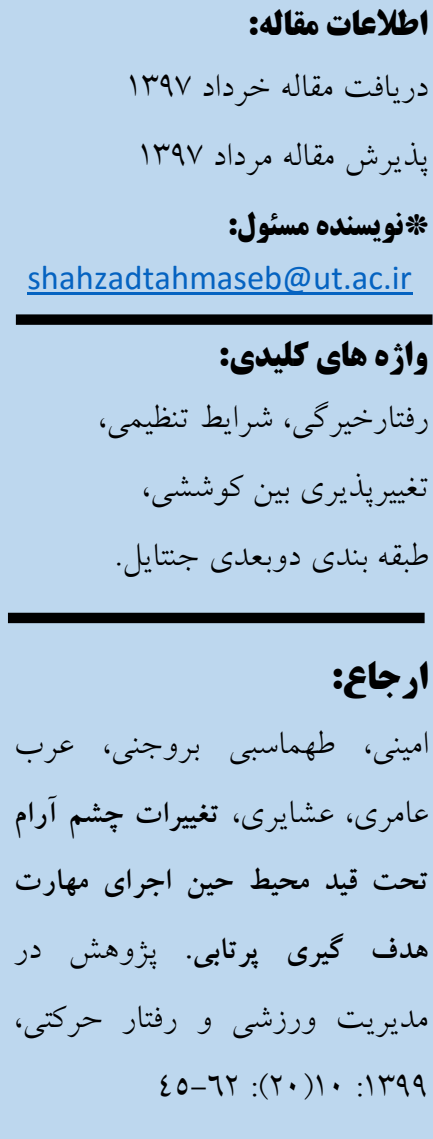 \\
\hline
\end{tabular}

$$
\begin{aligned}
& \text { ع. استاد دانشكده علوم تو انبخشى، دانشخاه علوم يز شكى ايران، ايران. }
\end{aligned}
$$




\section{مقدمه}

اهميت اجراى ورزشـكاران در ميادين ورزشسى، محققان را بر آن داشـته اسـت كه با ارزيابى دقيق اجرا در شرايط متفاوت، عوامل مختلف مؤثر بر اجرا و يادكيرى مهارتهاى حركتى را تحليل و شنا سايى نموده و با

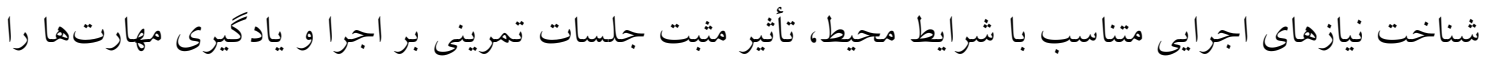

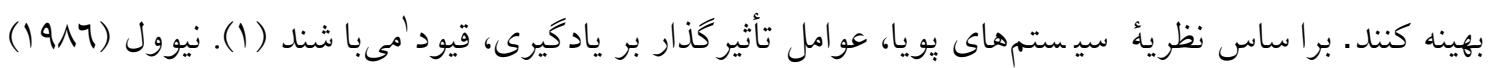

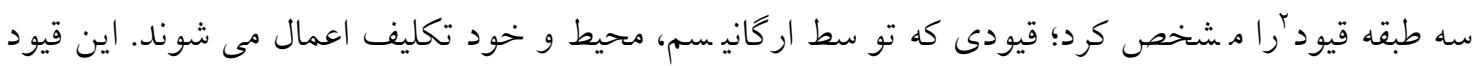

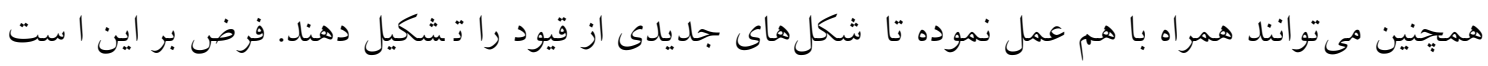

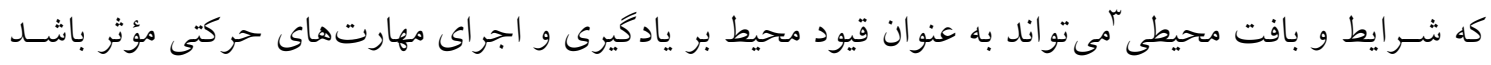

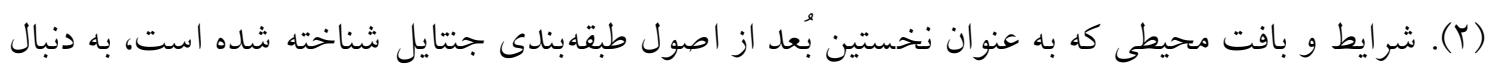

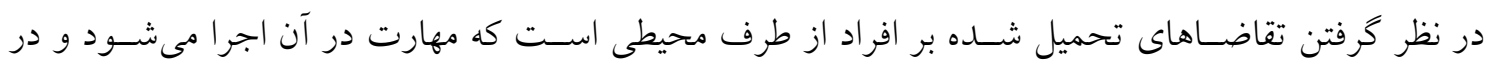

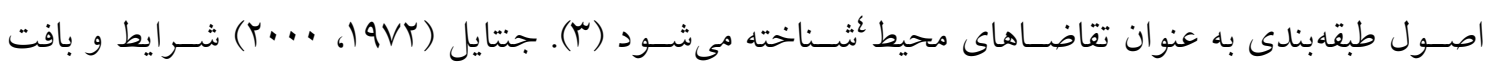

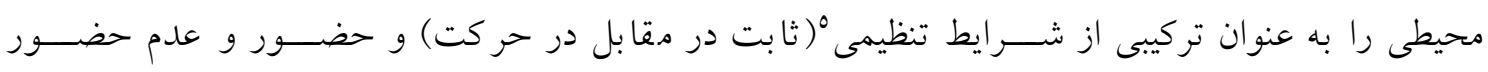

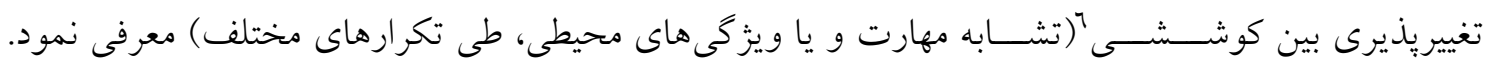

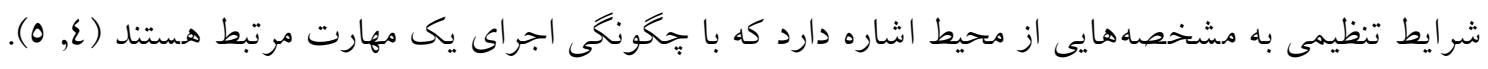

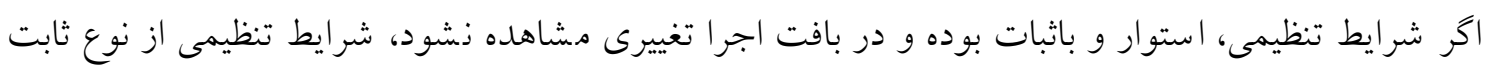

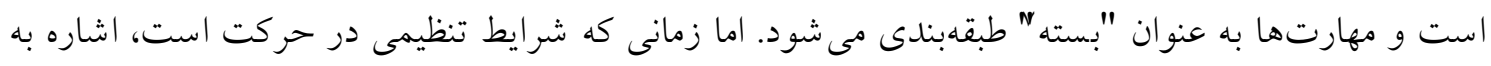
اين دارد كه مـ شخ صههاى محيطى مرتبط تغيير يافته يا در طول اجراى مهارت در حركت هـ ستند و مهارتهاتها

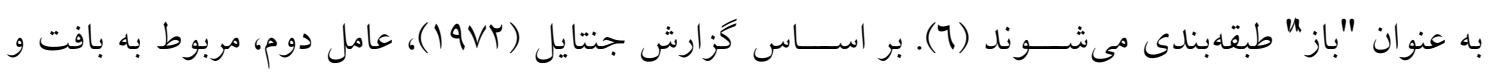

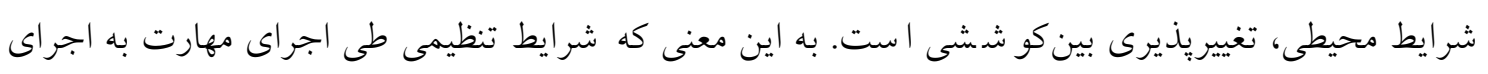

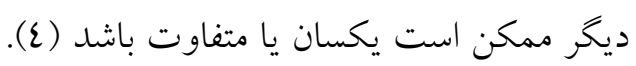

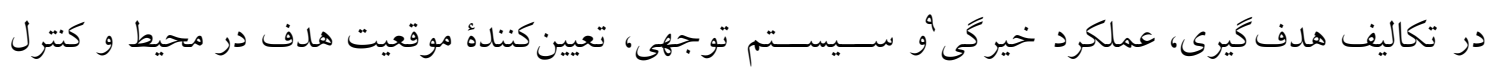
هدف گيرى شـىء در ناحية هدف اسـت. تكاليف هدف گيرى به سـه زير مجموعه تقسـيم مى شـوند، كنترل

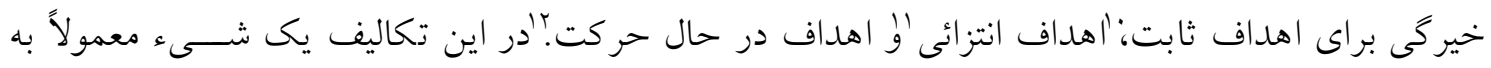

1 -Constraint

2 -Gentile's Dimensions

3 -Environmental constraints

4 -Environmental demands

5 -Regulatory conditions

6 -Inter-trial variability

7 -Closed

$\boldsymbol{8}$-Open

9 -Gaze performance

1 - Fixed targets

1 -Abstract target

1 -Target in motion 
بيرون از بدن بو سيلهُ دستها يا ياها به سوى هدف يرتاب مى شود و دقت و همسانى عملكرد، هدف نهايى است و تمركز بر روى حياتى ترين بخش هدف و زمان اكتساب اطلاعات مهم است و جفت شدكى بهينه بين

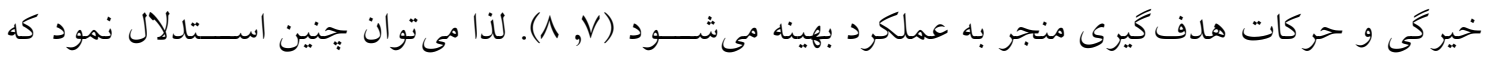
عملكرد مطلوب در تكاليف هدف گيرى، تحت تأثير راهكارهاى ادراكى - شناختى قرار دارد (9).

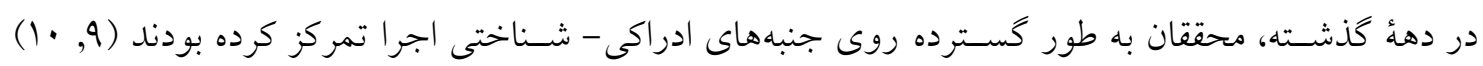
برترى بازيكنان ماهر بر بازيكنان غيرماهر بر بائهُ يُزوهشهاى گسترده و بر اساس تستهاى طراحى شده در.

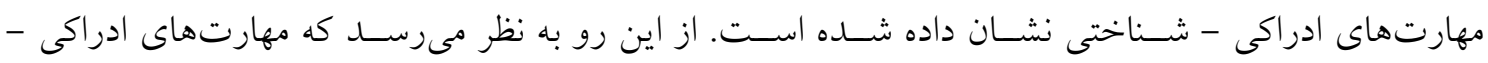

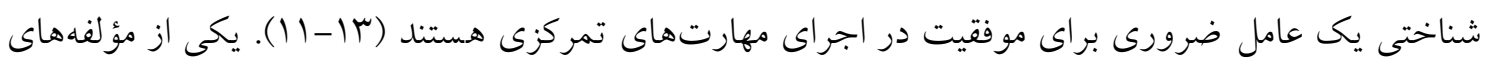

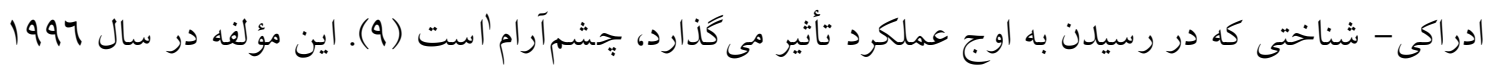

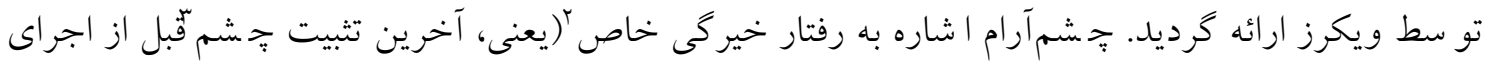

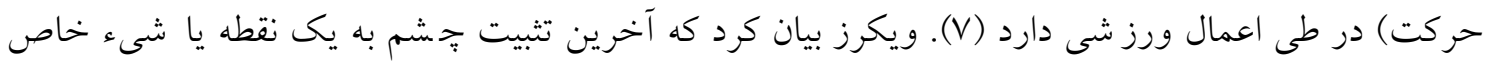

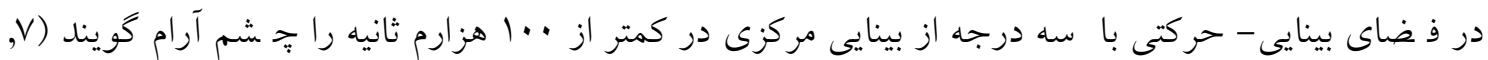

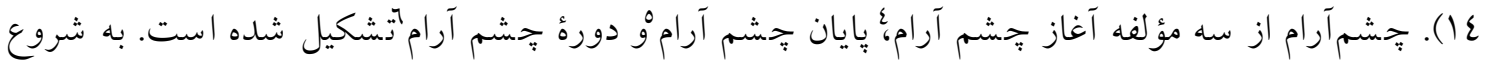

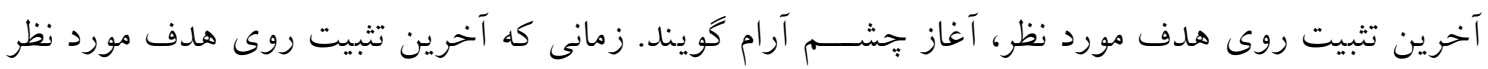

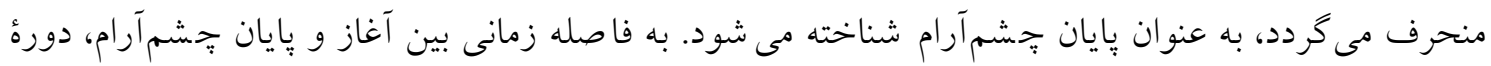

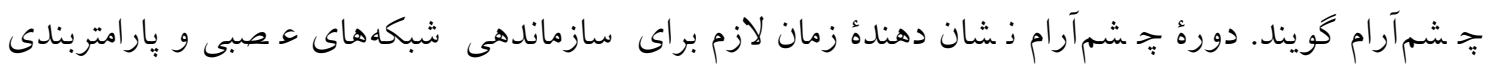
بينايى است كه مسئول كنترل حركات دقيق مىباشد. در طول اين دوره اطلاعات حسى با مكانيسمهاى لازم براى برنامهريزى و كنترل در لحظه، براى ايجاد ياسـخ حركتى مناسـب تركيب مى شـود. هر دو عامل شـروع

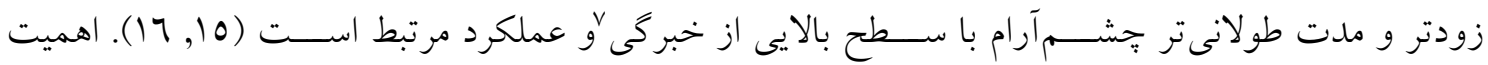

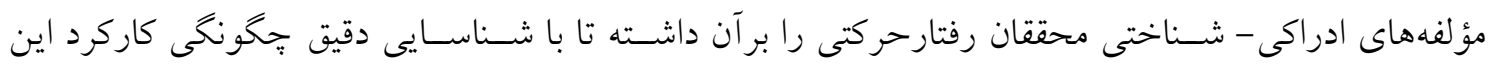

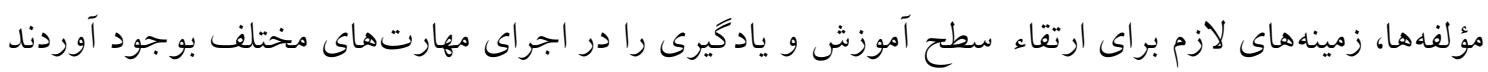

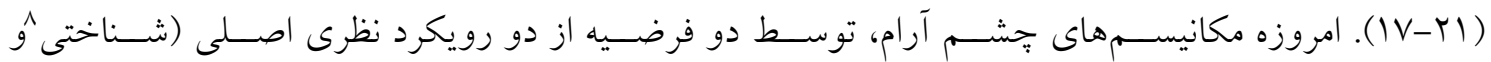
بوم شناختى" مورد بررسى قرار مى گيرد. تاكنون، رويكردهاى شناختى و بومشناختى (كه قبلا به عنوان رويكرد

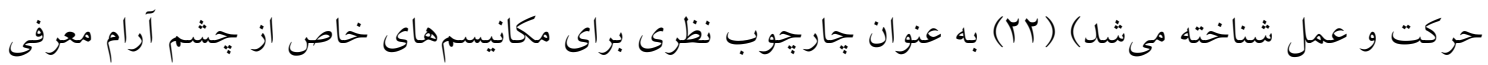

1 -Quiet eye

2 -Specific gaze behavior

3 -Eye fixation

4 -Quiet eye onset

5 -Quiet eye offset

6 -Quiet eye period

7 -Expertise

$\boldsymbol{8}$-Cognitive

9 -Ecological 
شده است. فر ضيه اصلى كه تاكنون از دامنه شناختى، تكامل يافته است، برمبناى طرحواره (T/T) مىباشد. بر

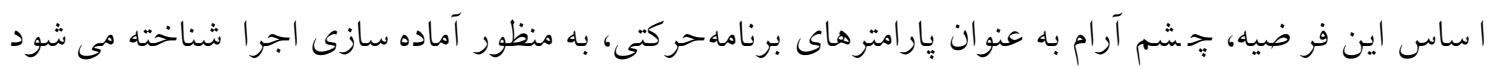
(فر ضيه برنامهحركتى) (ع (Y). در مقابل رويكرد شناختى، رويكرد بوم شناختى برمبناى تئورى ادراك مـ ستقيم

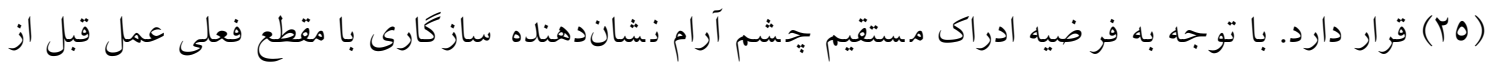

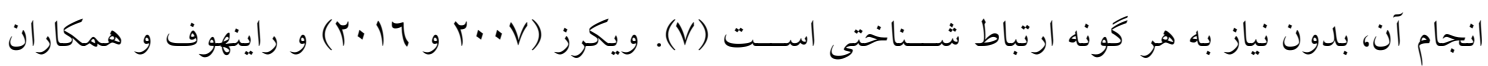

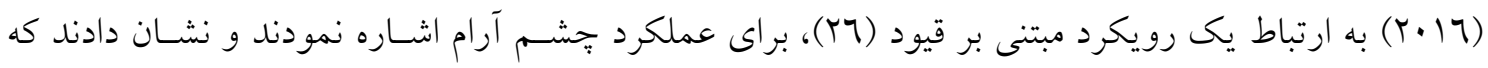

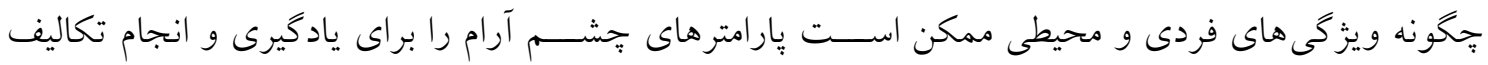

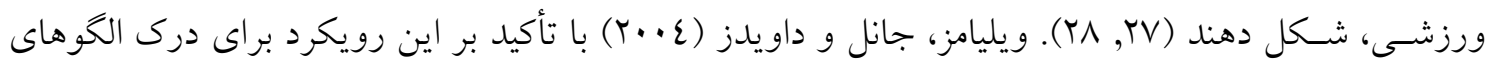
جستجوى بينايى، جنين ا ستدلال كردند كه افراد نياز به انجام رفتارهاى سريع و مداوم در تعامل با قيود ارائه

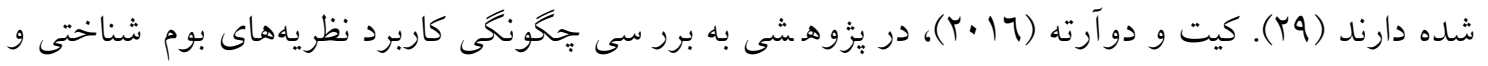

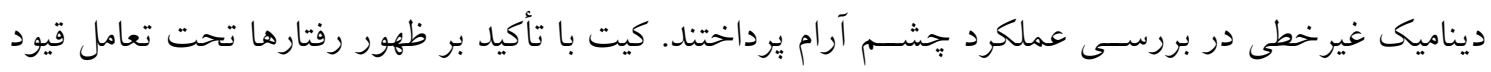
فرد، تكليف و محيط، به اين مو ضوع اشاره داشت كه نياز است تا با توجه به يويايى محيط، تحقيقاتى درباره

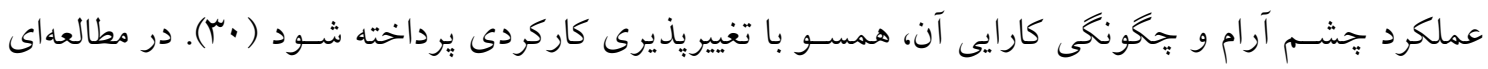

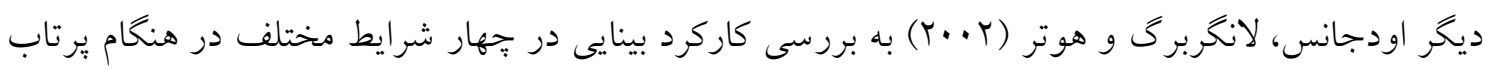

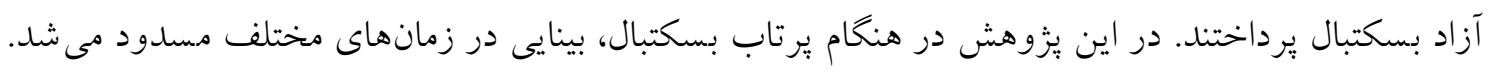

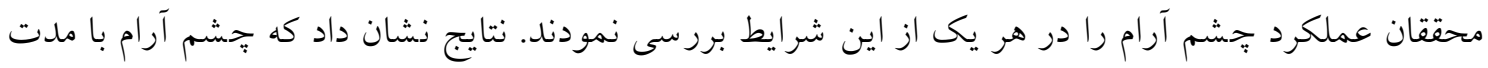

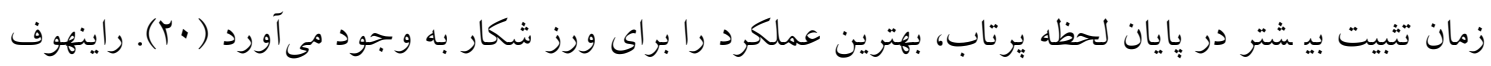

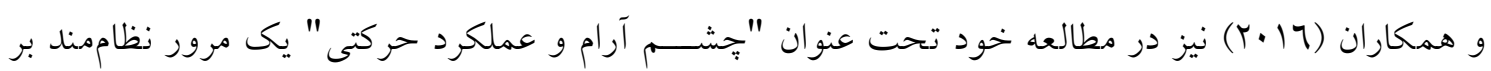

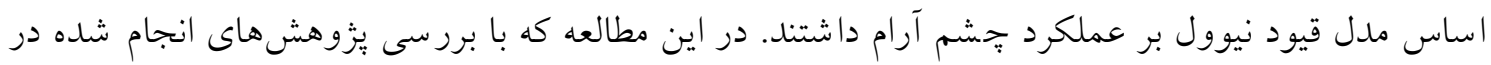

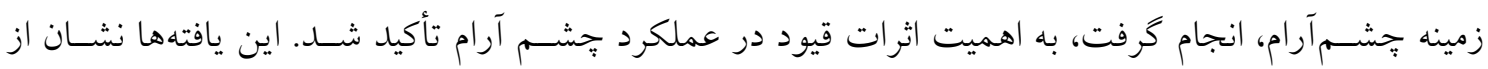

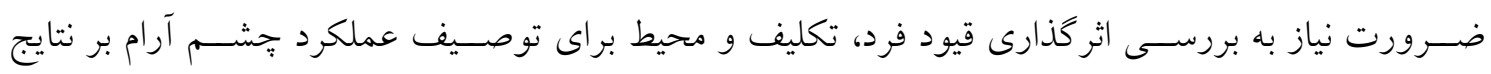
يادكيرى و اجراى مهارتهاى حركتى دا شت (YV). تحقيقات انجام شده تأييدى بر اين ايده است كه اثرات قيود مختلف ممكن اسـت بر عملكرد جشــم آرام تأثير كذاشـته و به بهبود عملكرد كمك كند. با اين وجود

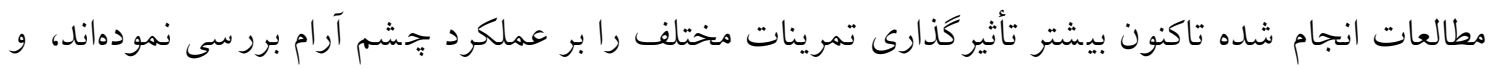
تاكنون قيود محيط بركرفته از يافته هاى جنتايل (I IVYT) و ايجاد شــرايط تغيير يذيرى بافت محيطى و بين

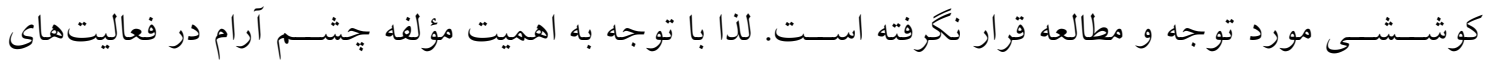
مختلف ورزشى و در راستاى تكميل تحقيقات كذشته و استفاده از ديدكاههاى نظرى جامعتر اين سؤال مطرح

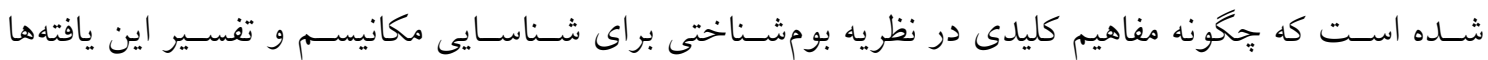
مىتواند مورد استفاده قرار كيرد. باتوجه به اينكه تغيير، از خصو صيات سيستمهاى بويا است و آنها همجنين با مقدار تغييرى كه امكانيذير است، محدود مىشوند (7)، مىتوان براساس ديدكاه بوم شناختى، انتظار داشت 


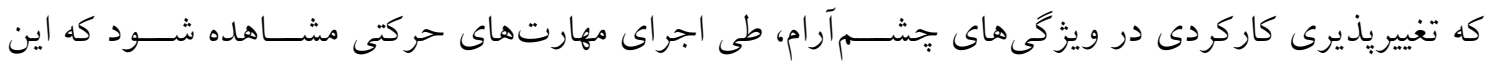
تغييرات مىتواند هم راستا با يذيرش قيود، متفاوت باشد. با بررسى مطالعات انجام شده در اين زمينه مىتوان

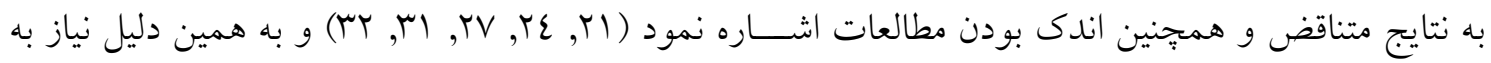

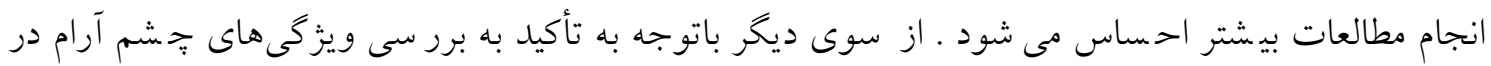

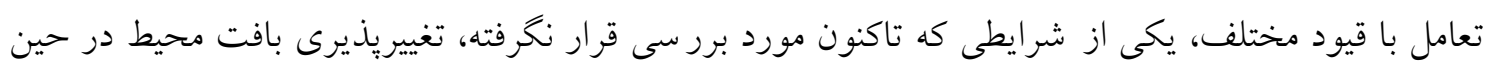

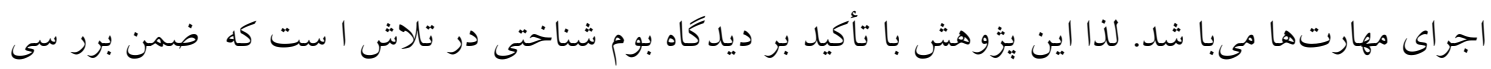

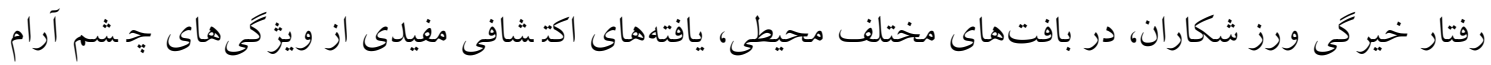

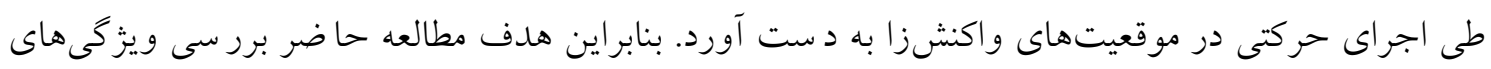

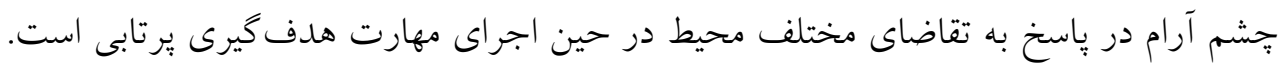

\section{روششناسى بُووهش}

اين يزوهش از نوع نيمهتجربى و داراى طرح درون كروهى جهت برر سى اثرات قيود محيط بود كه در آن اثر تعامل الكوهاى شرايط تنظيمى (ثابت / در حال حركت) و تغييريذيرى بين كوششى (با / بدون تغييريذيرى) بر بر برى

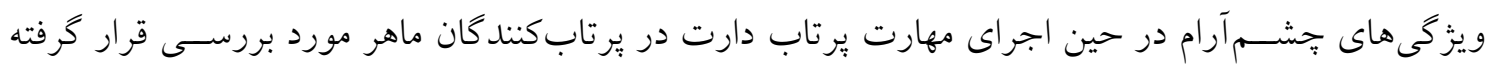

\section{جامعه و نمونه آمارى}

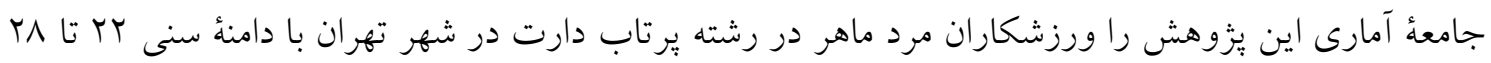

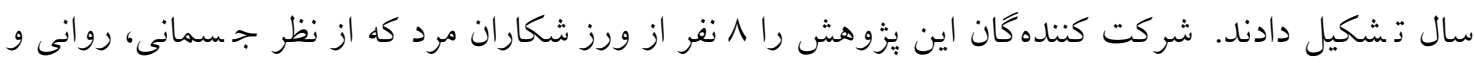
نورولوزيكى از سلامت كامل برخوردار بودند و حداقل ينج سال سابقه آموزش و تمرين ر سمى و حرفهاى دارت دا شتند، ت شكيل مىدادند. از معيارهاى ورود در يزوهش حا ضر، را ستد ست بودن، دا شتن سابقه آموزش رسمى در زمينهُ مهارت دارت و سابقهُ شركت در مسابقات و تمرينات ويزٔه دارت بود. براى اطمينان

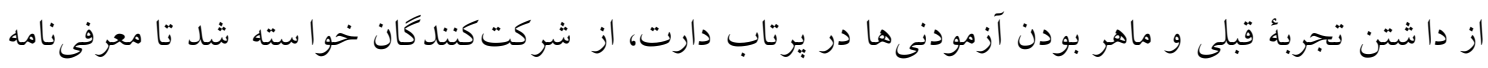

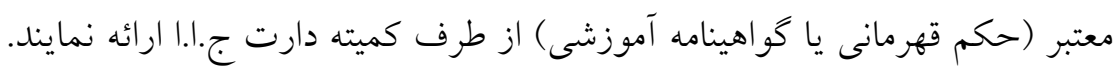

ابزار اندازهيرى

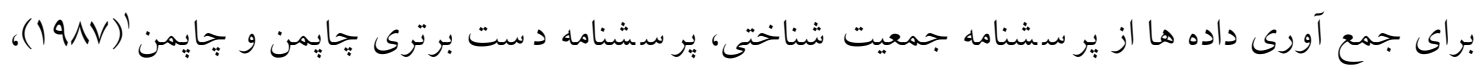

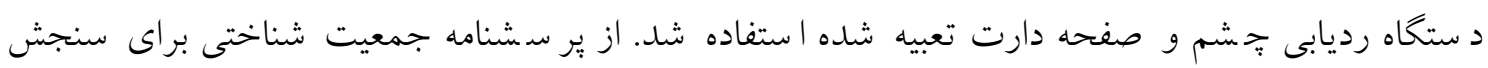

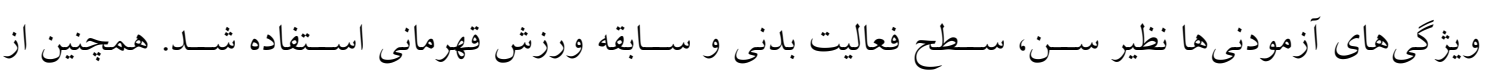

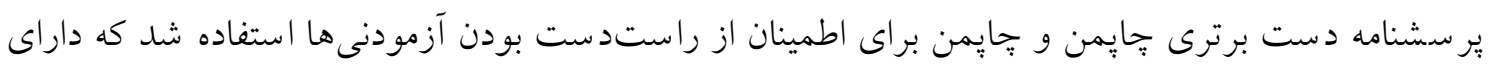

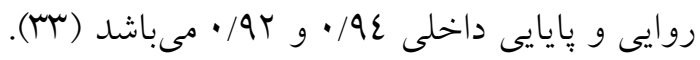

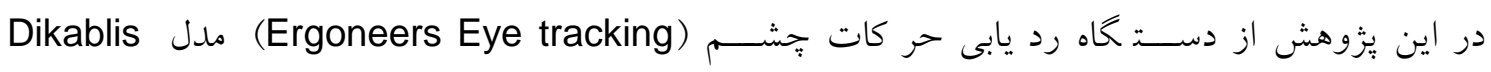

1- Chapman \& Chapman Handedness Questionnaire 
ساخت كميانى ERGONEERS كشور آلمان كه نقطه خيركى در هر لحظه را با فركانس •9 هرتز ثبت مى كردد، اسـتفاده شـد. اين سـيستم شـامل عينك مجهز به دوربين و دستشكاه ضـبط يورتابل بود. دادههاى به دست آمده از طريق سيستم وايرلس به صورت نوار ويدوئى به كامييوتر داراى قابليت

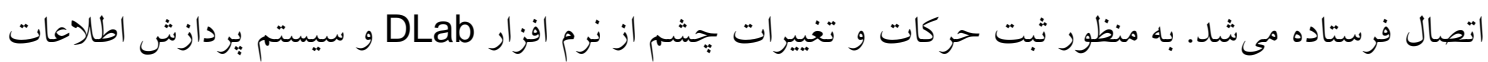

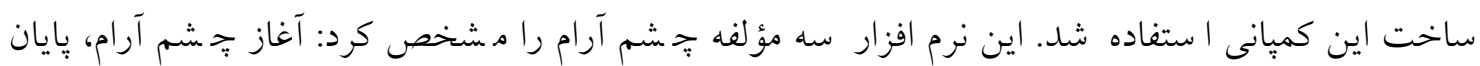

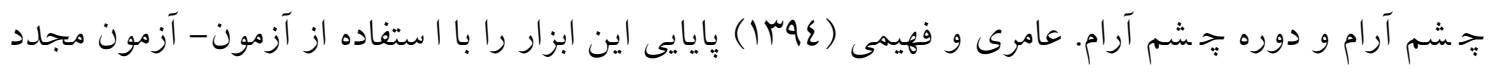

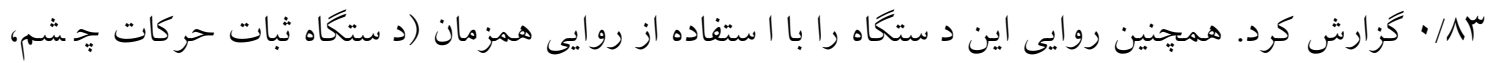

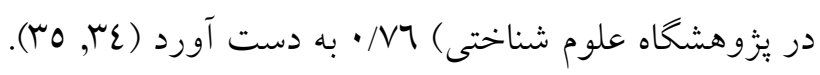

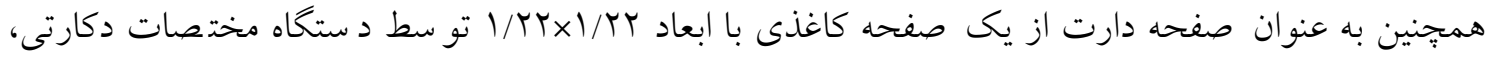

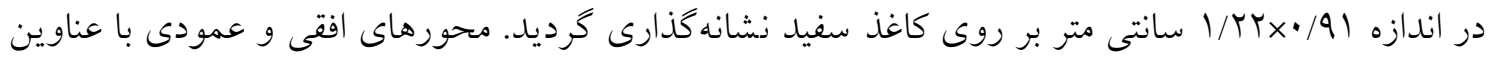

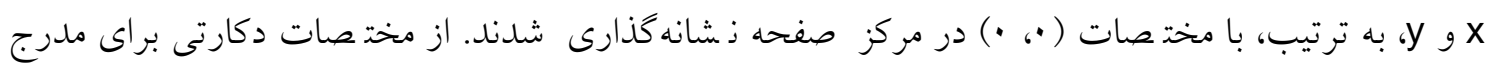
كردن موقعيت هدف، قبل از جمع آورى دادهها و براى اندازهذيرى مختصـات X و Y از موقعيت دارت يرتاب

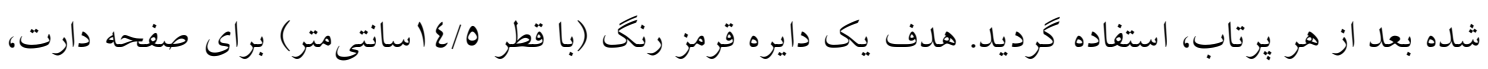
تهيه شد. هدف تو سط يك نرم افزار كامييوترى 'طراحى شده و از طريق يك ويدئو بروزكتور اينفوكوس مدل IN112 بر روى صفحه دارت كتترل شد. هر شركت كننده در فاصله ب مترى از صفحه و در سمت راست يروزكتور مىايستاد و تكليف برتاب دارت (•^ يرتاب) در يكى از جهار شر ايط محيطى انجام مىداد (Y).

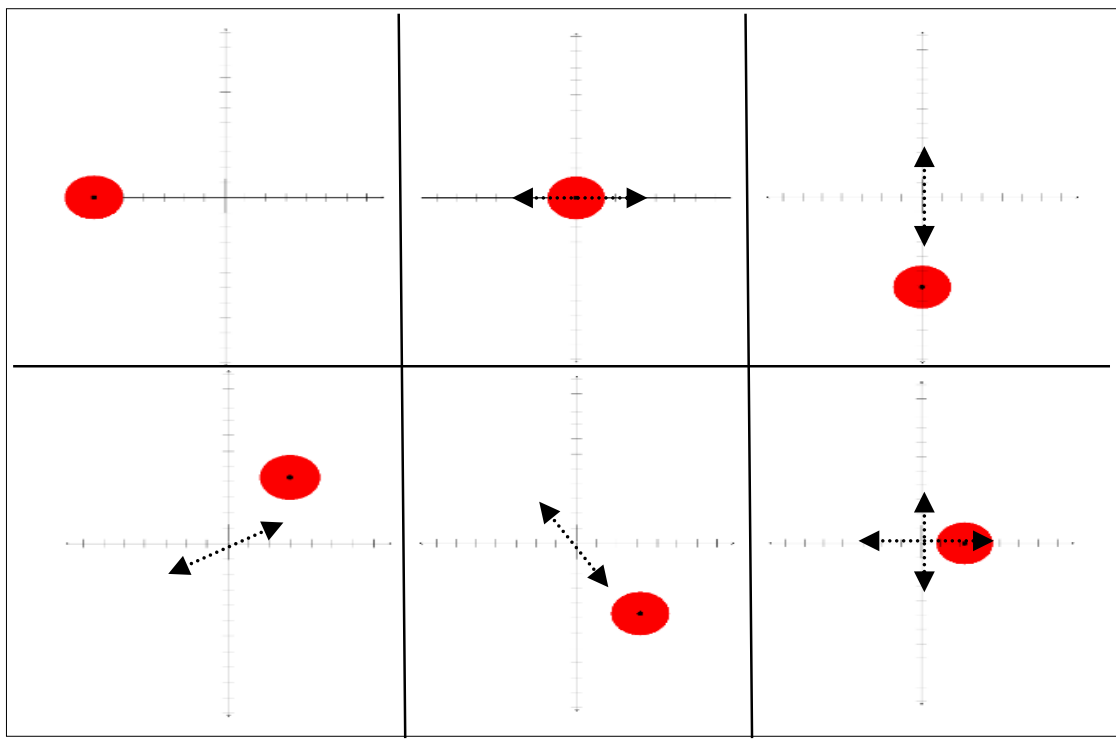

شكل ا- برخى الكوها از نحوه حضور و حركت هدف برروى صفحه دارت

1 -Lab- VIEW National Instruments Corp., Austin, TX 


\section{روش اجرا}

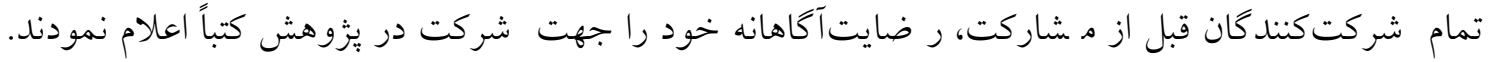

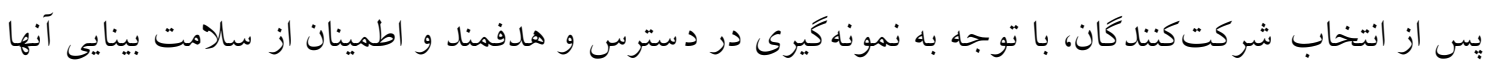

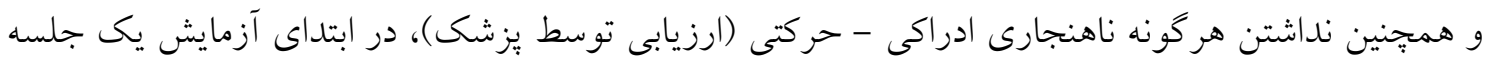

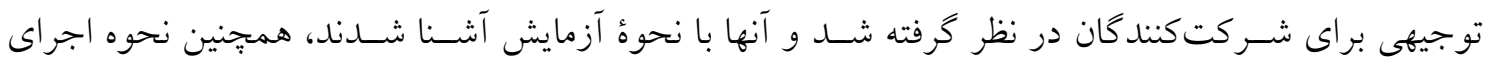

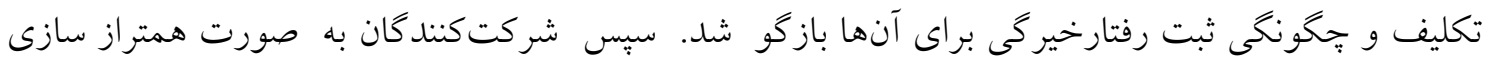

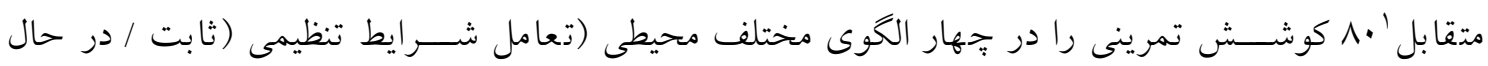

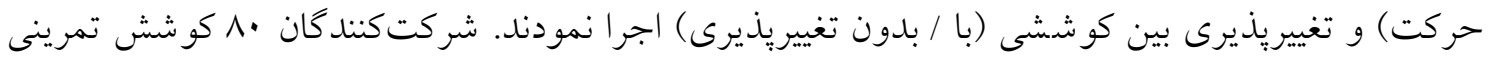

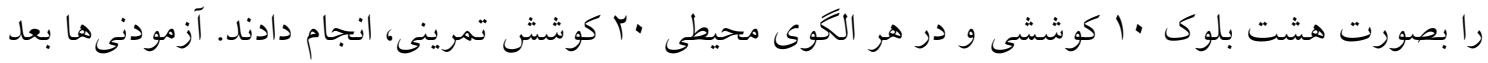

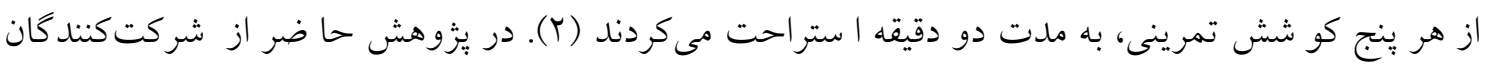

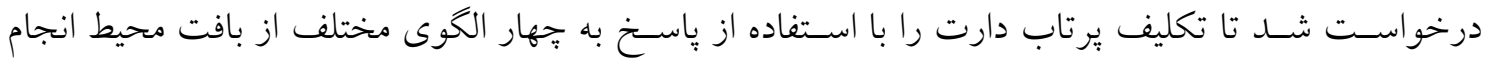

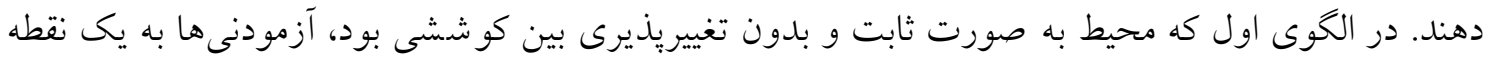

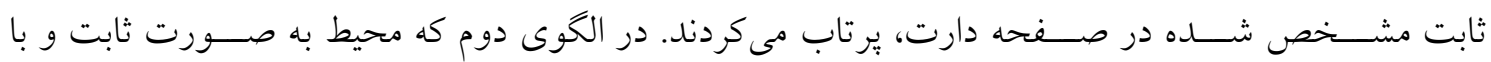

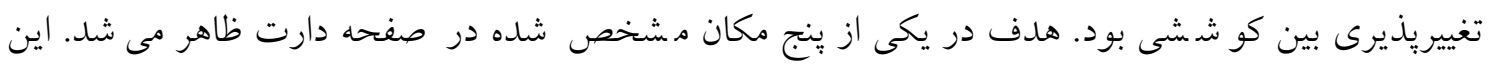

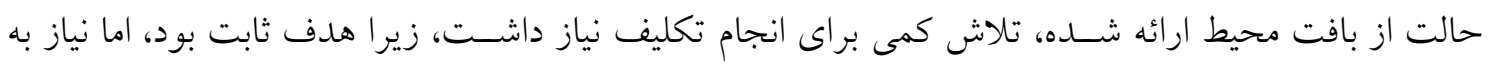

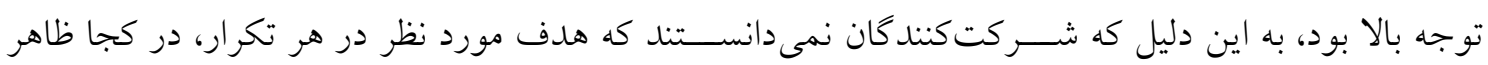

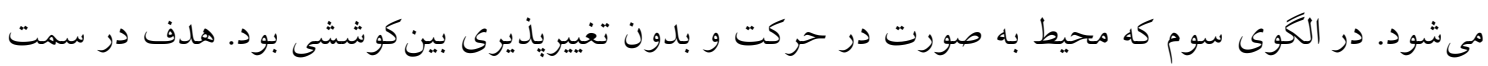

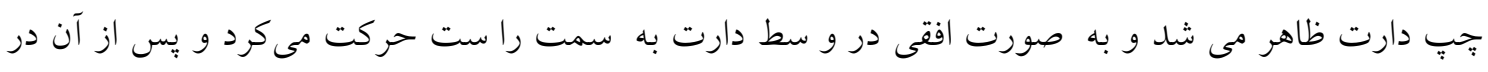

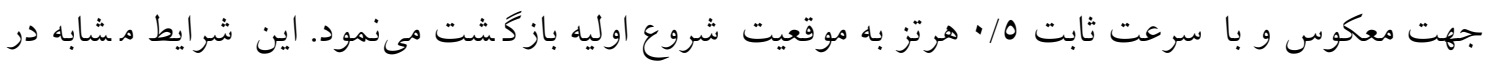

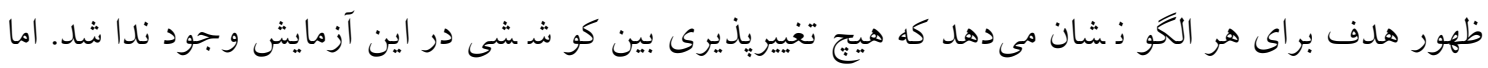

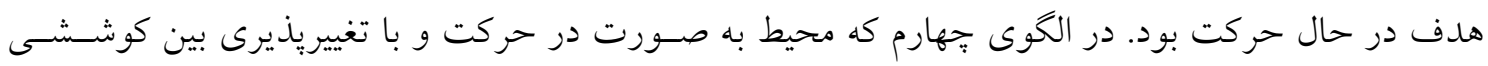

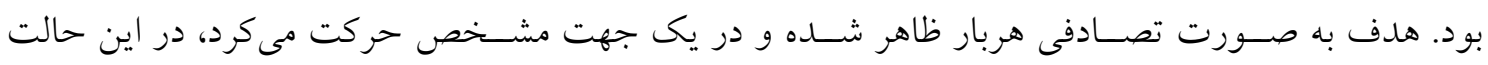

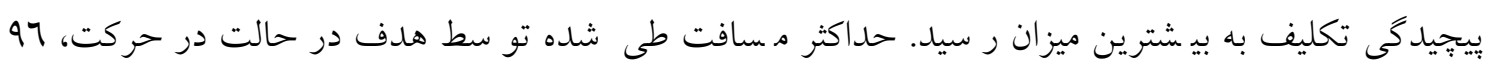

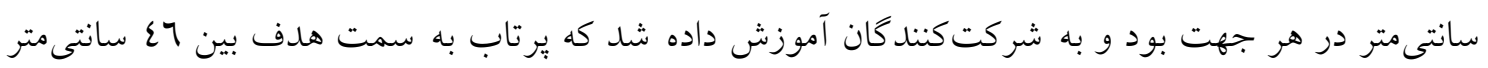

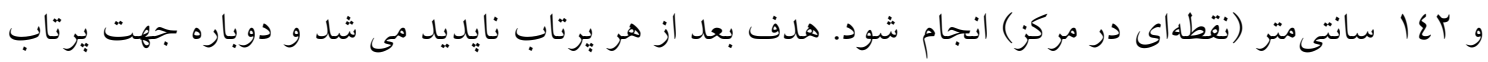

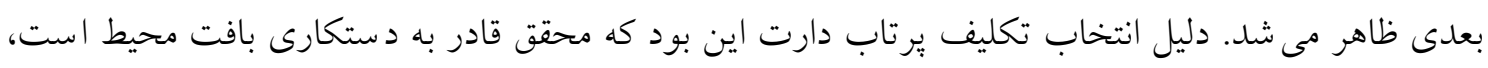


در حاليكه اجر اكننده به صورت ثابت مى ماند، و امكان مقايسه نتايج در ميان شرايط مختلف محيطى را فراهم

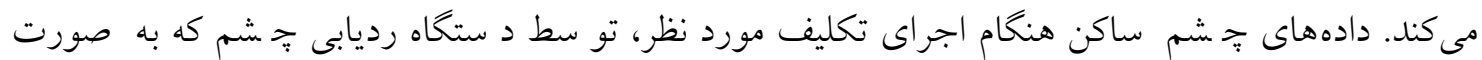

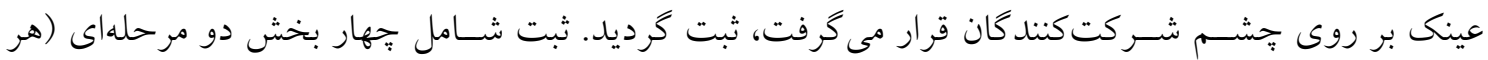

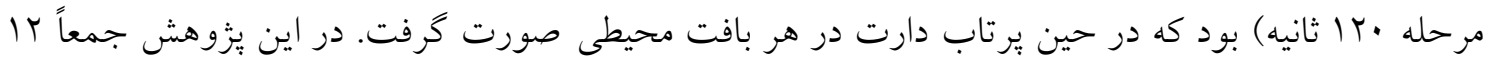

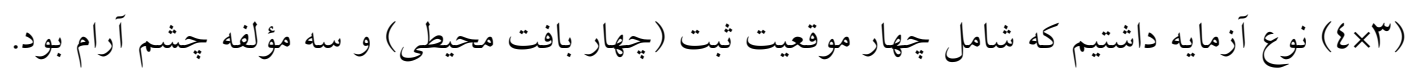

\section{روش آمارى}

در سطح تو صيفى، از محا سبهُ ميانخين و انحراف معيار و در سطح ا ستنباطى يس از برر سى توزيع دادهها با

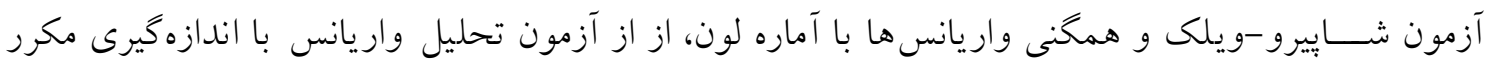

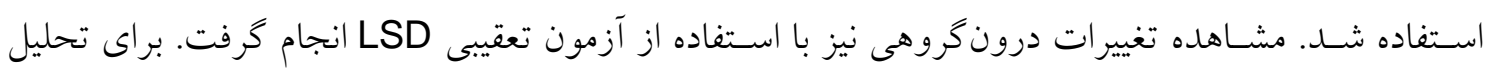

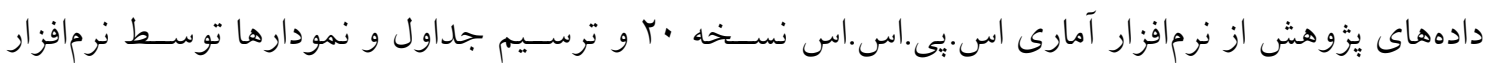
اكسل نسخه 11 • r، در سطح معنى دارى 0 •/ P استفاده شد.

\section{نتايج و يافته هاى يخووه}

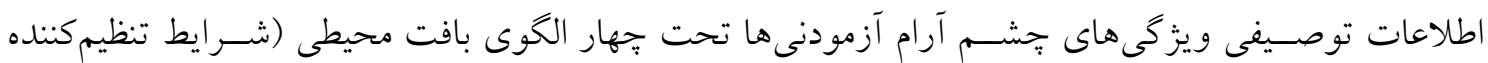
(ثابت / در حال حركت) و تغييريذيرى بين كوششى (با / بدون تغييريذيرى) در جدول ا ارائه شده است.

\begin{tabular}{|c|c|c|c|c|c|c|}
\hline \multicolumn{2}{|c|}{ دوره جششم آرام } & \multicolumn{2}{|c|}{ پِيان جششم آرام } & \multicolumn{2}{|c|}{ آغاز جشم آرام } & \multirow[b]{2}{*}{ بافت محيطى } \\
\hline انحر اف معيار & ميانخين & انحر افمعيار & ميانخين & انحر افمعيار & ميانخين & \\
\hline$T / M T$ & $70 \mathrm{~V} / \mathrm{VO}$ & $1 / 01$ & $V \wedge I / 7 r$ & $r / 7 \varepsilon$ & $\mid K M / \Lambda$ & الكوى اول \\
\hline $1 / \mathrm{VV}$ & TrT/O. & $r / \cdot 0$ & $1 \cdot 9 / 20$ & $1 / 91$ & IVT/YO & الخوى دوم \\
\hline$\{/ r)$ & $\mathrm{VI} / \mathrm{ro}$ & $1 / 91$ & $107 / 70$ & $T / N T$ & $|\varepsilon v \cdot|$ & الخوى سوم \\
\hline$r / \cdot 7$ & $79 \cdot / 10$ & $1 / 71$ & $19 \cdot / \cdot 1$ & I/Ar & $199 / 70$ & الخوى جهارم \\
\hline
\end{tabular}

$$
\begin{aligned}
& \text { الكوى اول - ثابت بدون تغيير يذيرى بين كوششى }
\end{aligned}
$$

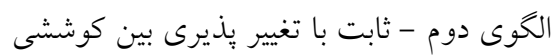

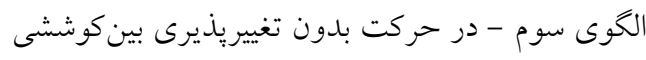

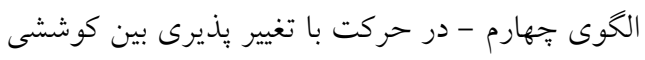

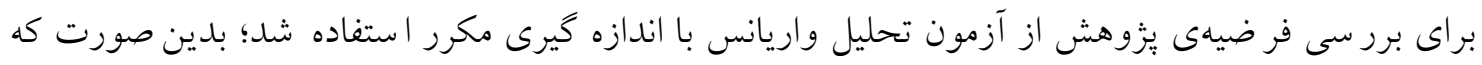

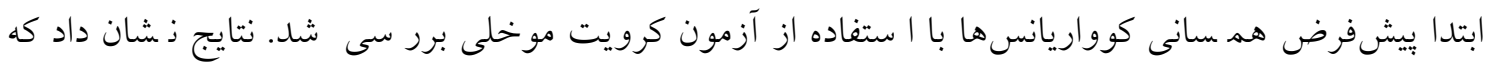

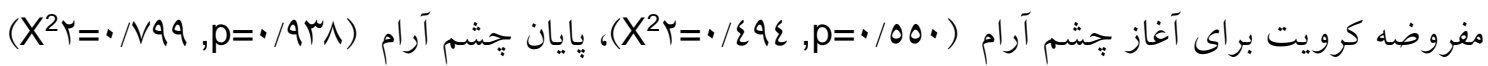

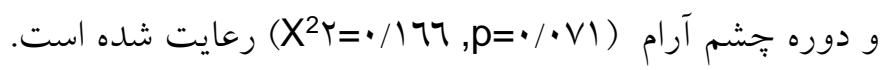


جدول r- نتايج تحليل واريانس مكرر براى بررسى ويزگى هاى خشم آرام

\begin{tabular}{|c|c|c|c|c|c|c|}
\hline مجذور ضريب & سطح معنى دارى & $F$ & مجانكين & درجهى & مجموع مجذورها & \\
\hline \multirow[t]{2}{*}{.$/ 990$} &.$/ \cdots 0$ & $\mid r r \cdot /$ TOI & AVQONNI & $r$ & ז & آغاز جشم آرام \\
\hline & & & $7 / 77 r$ & Y & $179 / 9.7$ & خطا \\
\hline \multirow[t]{2}{*}{.$/ 999$} & $\cdot / \cdots 0$ & orEV/TVV & $1107 \varepsilon / T A 1$ & $r$ & $0079 Y / \Lambda \varepsilon \varepsilon$ & يايان جشم آرام \\
\hline & & & $r / \Sigma V T$ & rI & $V Y / 9.7$ & خطا \\
\hline \multirow[t]{2}{*}{.$/ 994$} &.$/ \cdots 0$ & AYT/NVO & ATrI/TRO & $r$ & rV৭TT/rVO & دوره جشم آرام \\
\hline & & & 1.11 .1 & r & TITITO & خطا \\
\hline
\end{tabular}

نتايج تحليل واريانس با اندازهيرى مكرر ذشان داد كه مقدار F محاسبه شده براى اثر اصلى آغاز جششم آرام

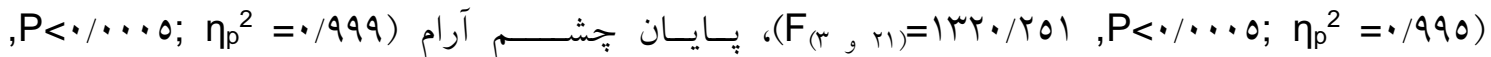

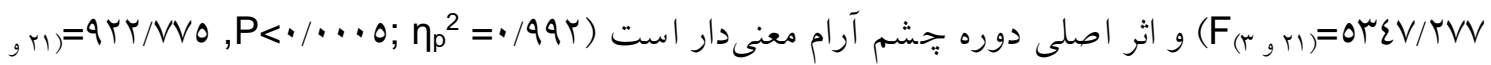

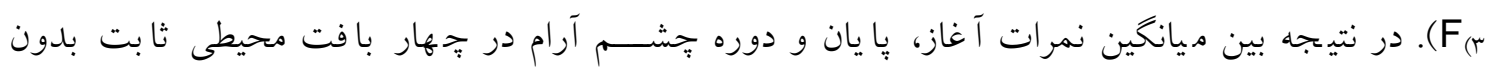
تغييريذيرى بين كوششى، ثابت با تغييريذيرى بين كوششى، در حركت بدون تغيير بذيرى بين كوششى و در

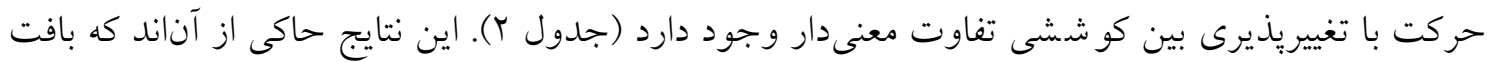

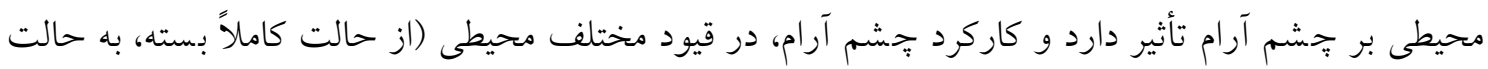

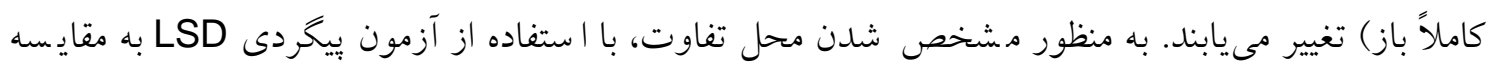

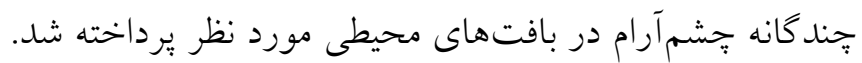

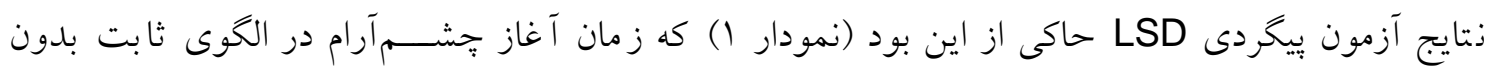

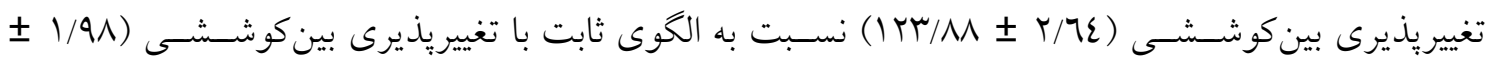

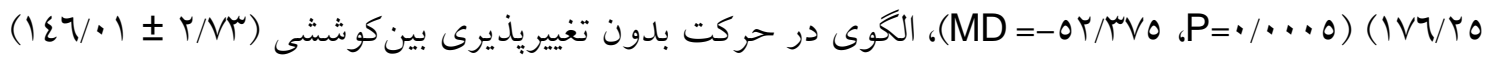

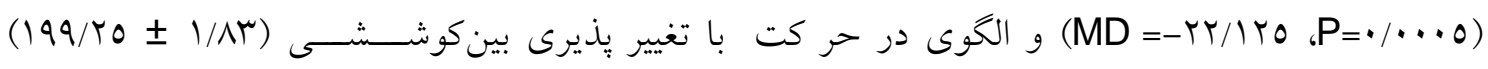
(MD=VO/rVO معنى دارى سريع ترى داشته است. همجنين الخوى در حركت بدون تغييريذيرى

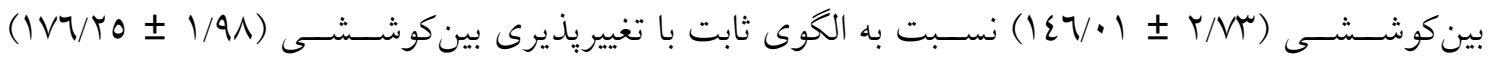

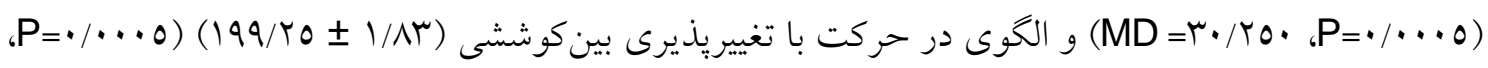

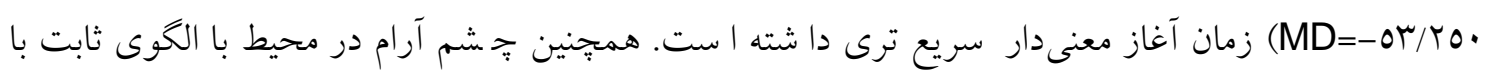

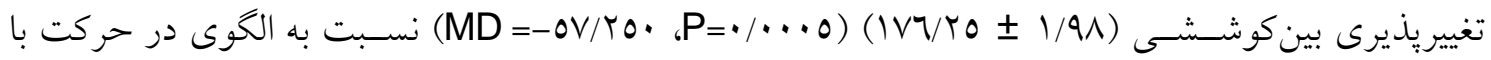

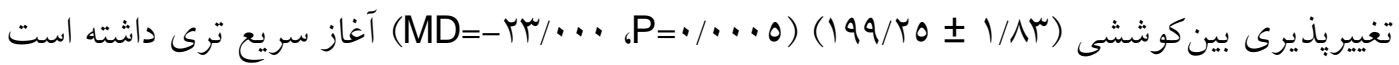




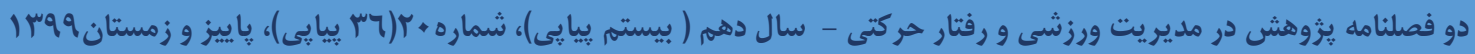

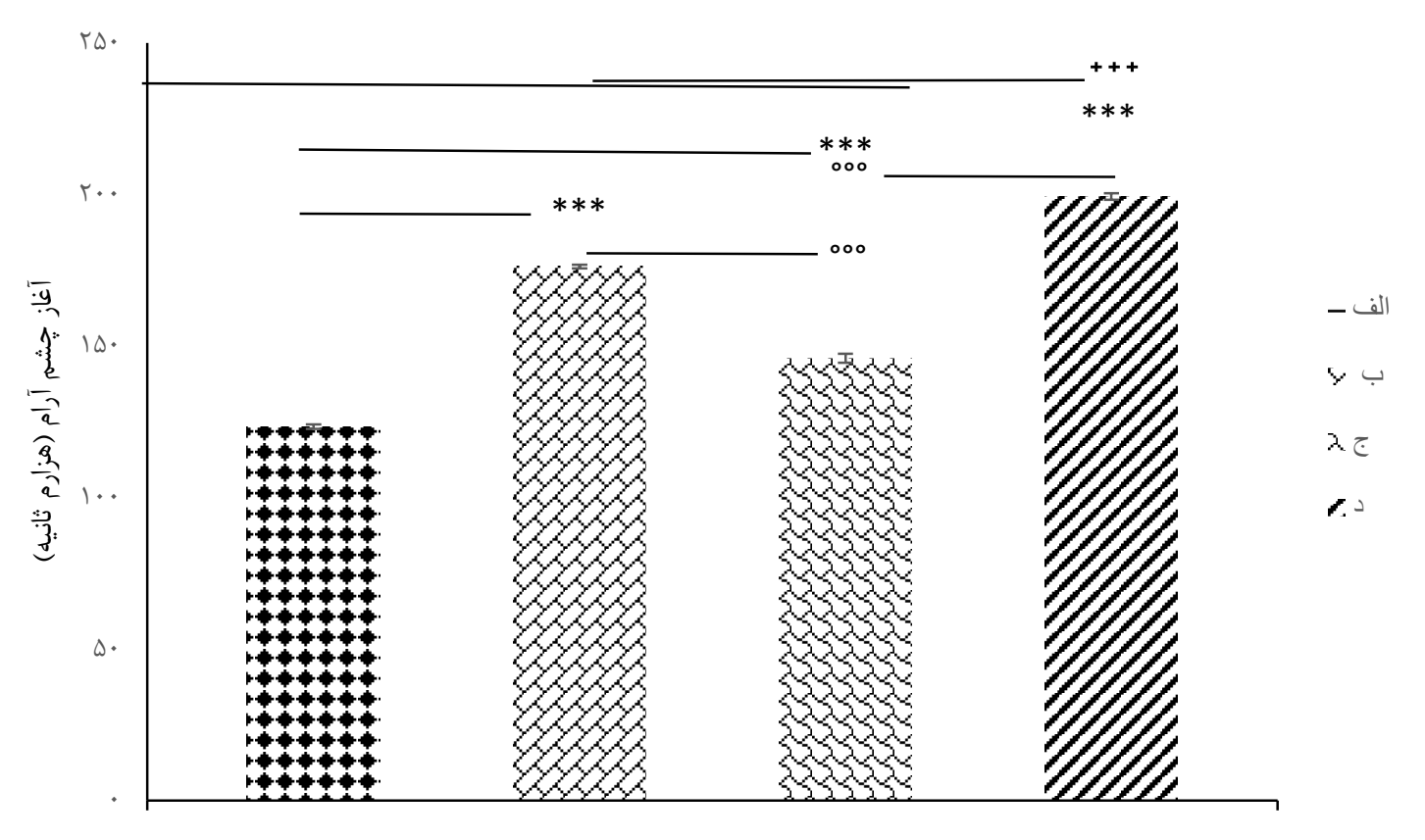

نمودار ا-مقايسةٔ ميانكين آغاز جشم آرام در جهار بافت محيطى (اطلاعات بر اساس ميانگين SEM براى 1 نمونه نشان داده شده است و

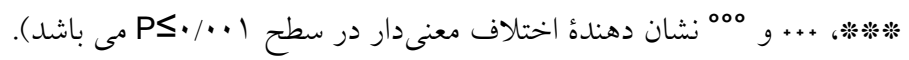

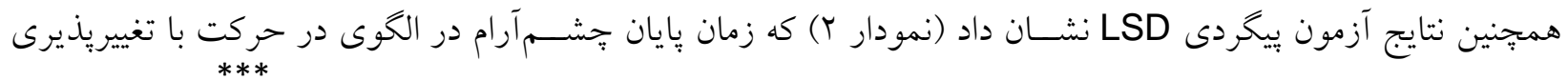

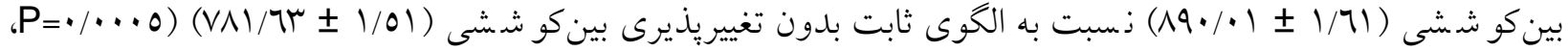

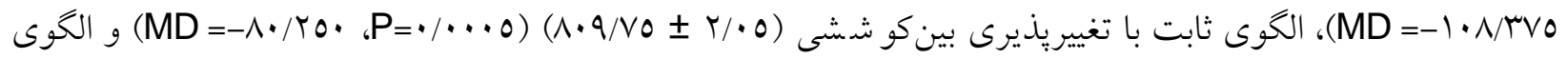

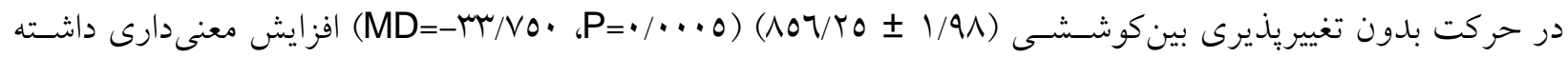

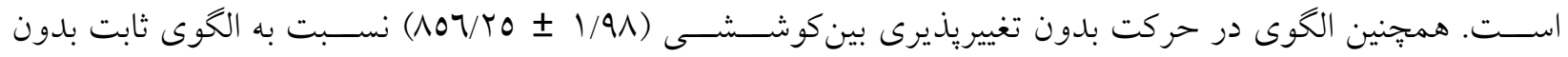

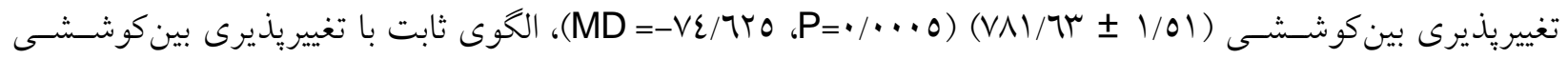

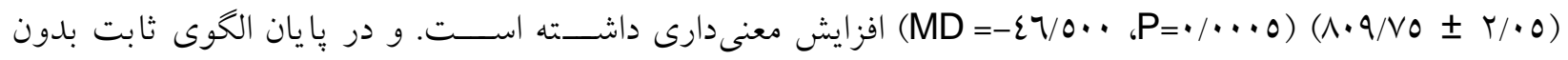

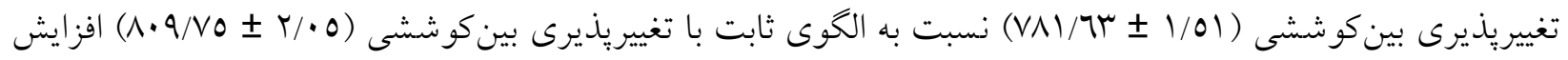

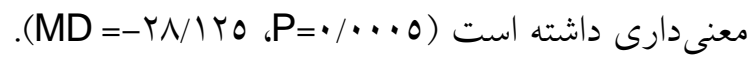

https://jrsm.khu.ac.ir/ 


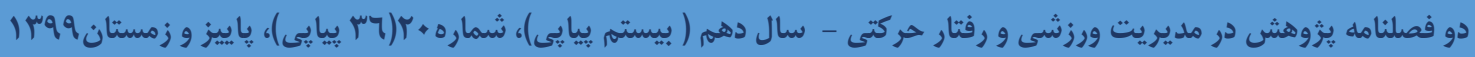

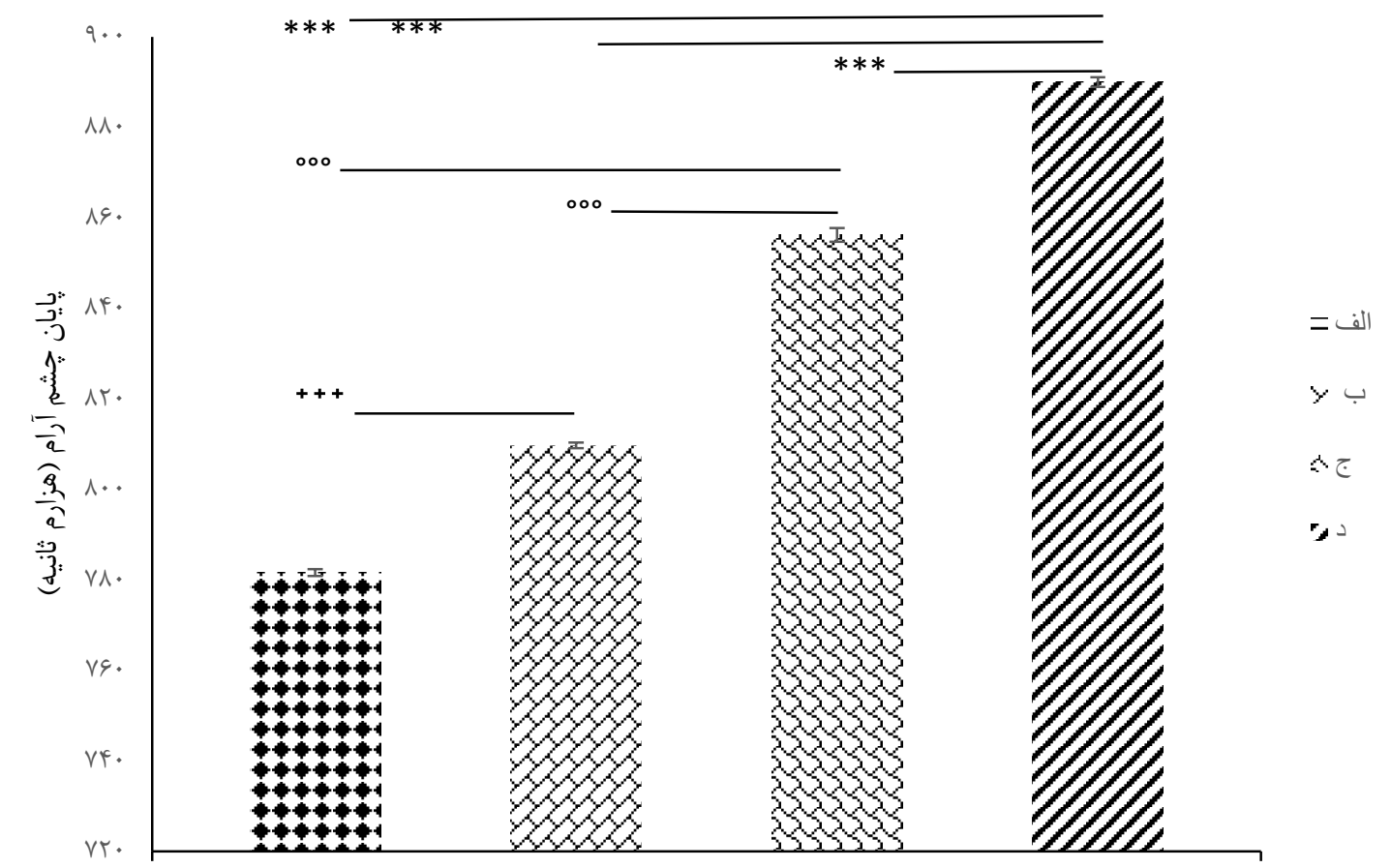

نمودار ץ- مقايسٔ ميانخين بايان جشم آرام در جهار بافت محيطى (اطلاعات بر اساس ميانخين SEM براى ^ نمونه نشان داده شده است و

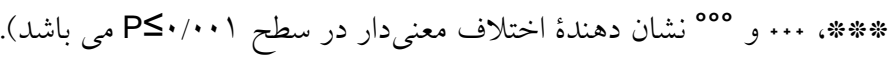

همان طور كه در نمودار ب نشـان داده شـده اسـت، نتايج آزمون ييخردى LSD حاكى از اين اسـت كه مدت زمان دوره:

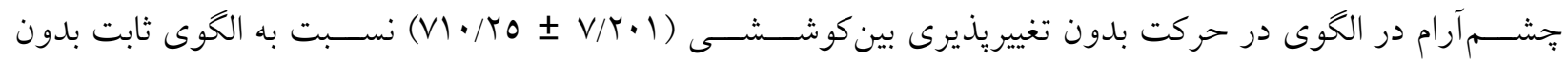

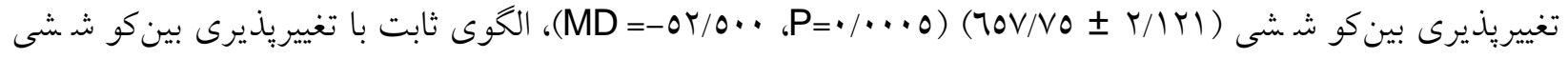

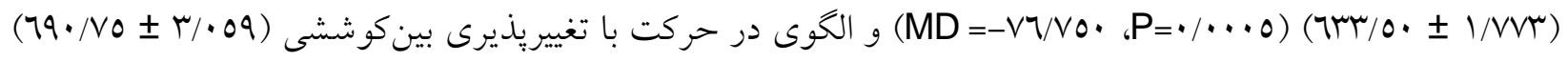
افزايش معنى دارى داشـته اسـت. همجنين الخوى در حركت با تغييريذ يرى بين كوشـشىى

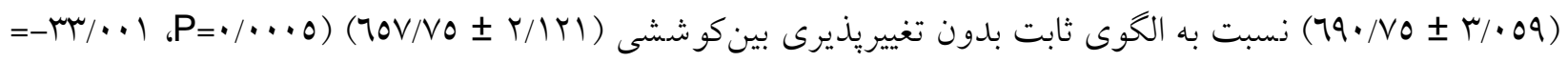
و الكوى ثابت با تغييريذيرى بين كو ششى (MDD

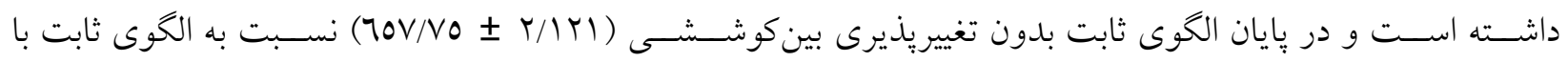

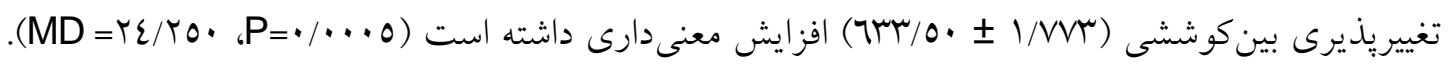




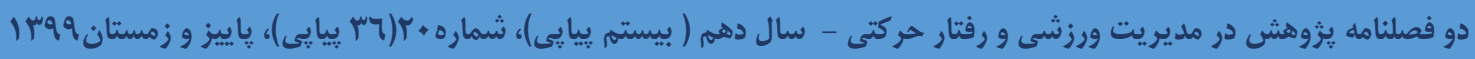

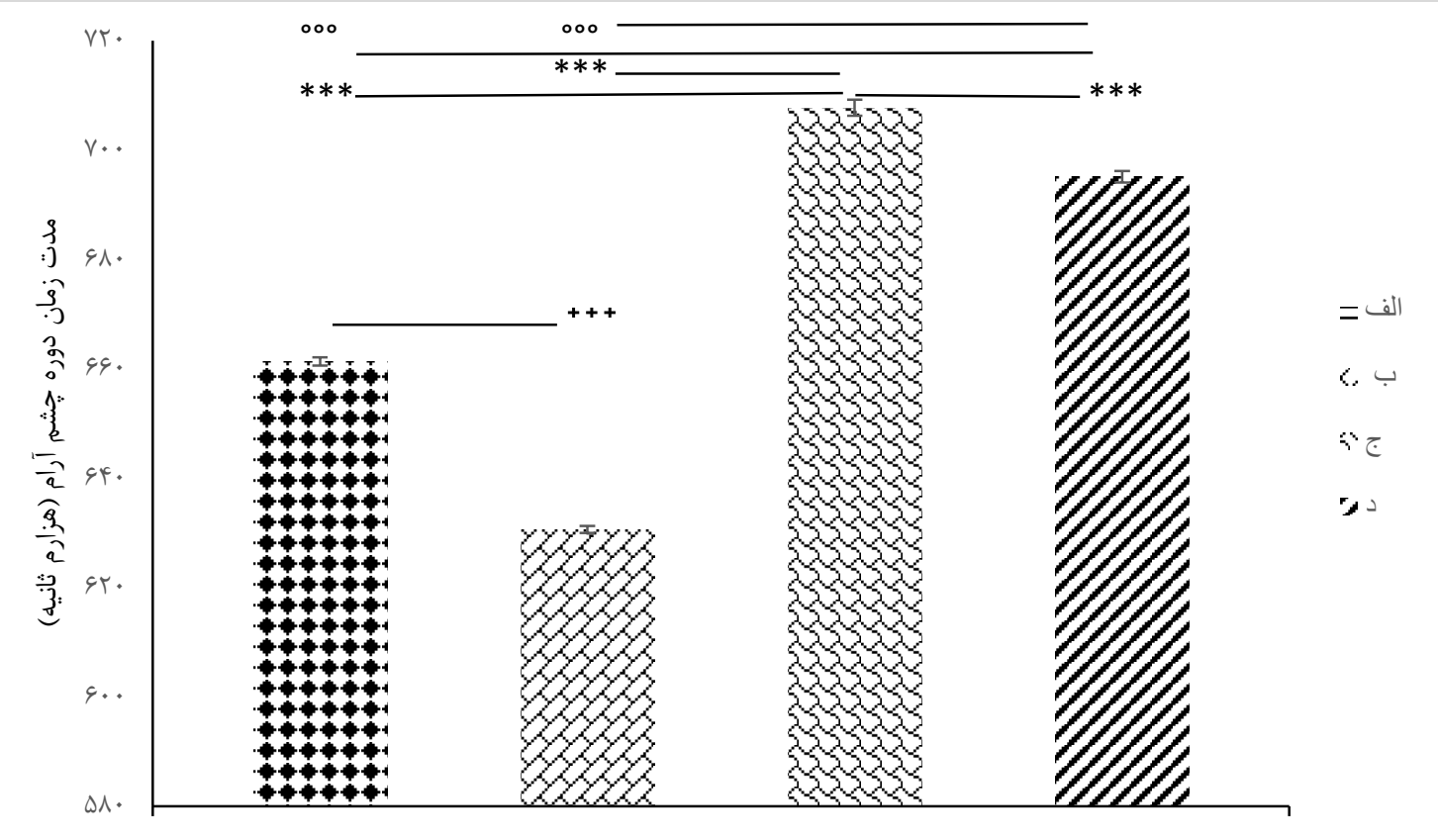

نمودار ب- مقايسة ميانحين مدت زمان دورة خشم آرام در خهار بافت محيطى (اطلاعات بر اساس ميانخين SEM براى 1 نمونه نشان داده

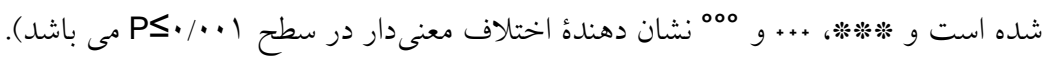

\section{بحث و نتيجه كيرى}

از جمله عوامل دخيل در اجراو ياد گيرى، بافت محيط است كه يكى از مهمترين زيرمجموعههاى قيود محيط محسوب

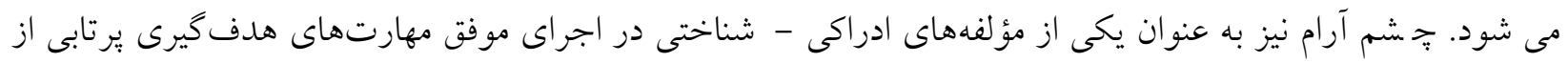

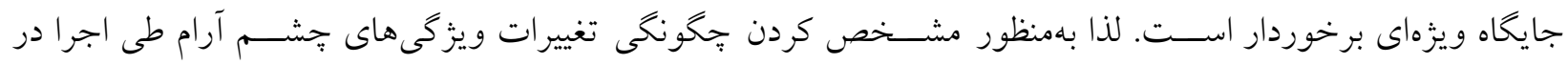

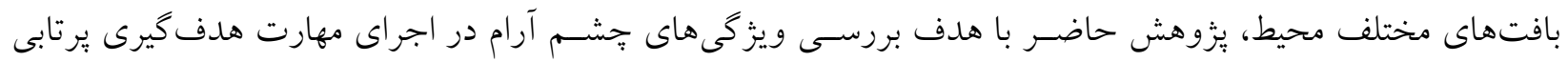

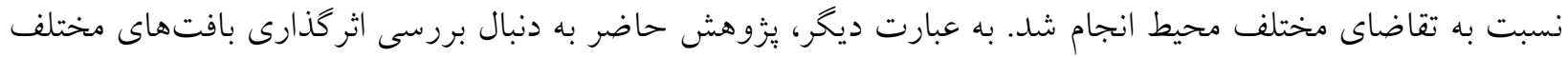
محيط (ثابت بدون تغييريذيرى بين كوشـشــى، ثابت با تغيير يذيرى بين كوشـشـىى، در حركت بدون تغيير يذيرى بين كو ششى و در حركت با تغييريذيرى بين كو ششى) بر مؤلفهاى مختلف خششم آرام (آغاز خششم آرام، يايان خجشم آرام، دوره جشــم آرام) در حين اجراى مهارت برتاب دارت يرتابكنند گان ماهر بود. براسـاس يافتهها و فرضسيه هاى موجود، فرض شـــد كه اجرا در بافتهاى مختلف محيط به عنوان قيود محيطى مى تواند نيازهاى رفتارى متفاوتى بر مؤلفه هاى جششم آرام اعمال كند. يافتهاى يزوهش حاضر توانست تا حدودى فرضيههاى يُزوهش حاضر را مورد تأييد قرار دهد و

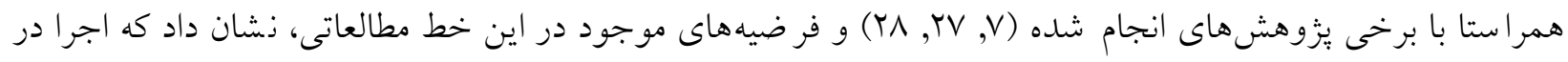
بافتهاى مختلف محيطى نيازمند ويز كى هاى جشــم آرام متفاوتى اسـت. به عبارتى دقيقتر هر يكى از بافتهاى محيطى

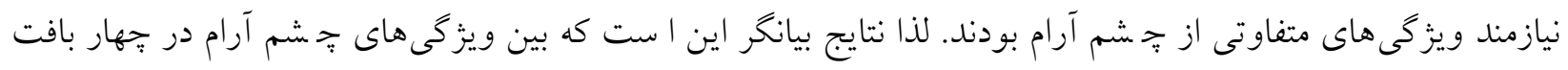

https://jrsm.khu.ac.ir/ 


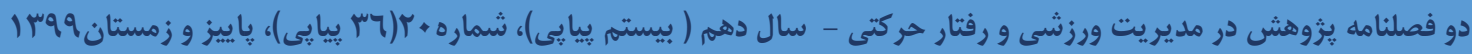

مختلف محيطى تفاوت معنى دارى مشـاهده شـد. بنابر اين قيود محيطى اعمال شـده باعث تغيير در مؤلفههاى جشــم آرام ورز شكاران كرديد، كه اين يافته به و سيله برخى فر ضيهها و نظريهها شرح داده شده است، براى مثال براساس فر ضيه ادراكى مـ ستقيم، خجشم آرام ساز گار با محيطى است كه مهارت در آن اجرا مى گردد، به عبارتى ارائه قيود مختلف محيطى

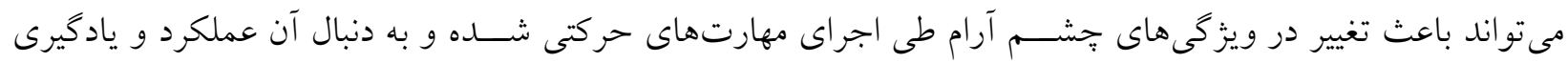
حركتى را تغيير دهد (V). لذا، شـايد بتوان از نتايج مطالعهُ حاضسر، بيشبينى هاى فرضسية ادراك مسـتقيم را درخصـوص تغييرات جشـــم آرام تأييد نمود؛ اين رويكرد بر ســاز كارى با مقطع فعلى عمل قبل از انجام آن، بدون نياز به هر كونه ارتباط شناختى براى جֶشم آرام تأكيد دارد. لذا مىتوان بردا شتهايى همسو از يزوهش حا ضر ا ستنباط كرد. يافتههاى مطالعاتى اخير در قالب مدل قيود نيول نيز اثر تغييردهنده بافتهاى محيطى را هـ شخص نمودهاند. بيشبينى هاى صورت كرفته توسـط اين فرضـيهها تا به امروز توسـط تأثير قيود بر عملكرد و يادكيرى مورد حمايت قرار كرفته اسـت (سار).

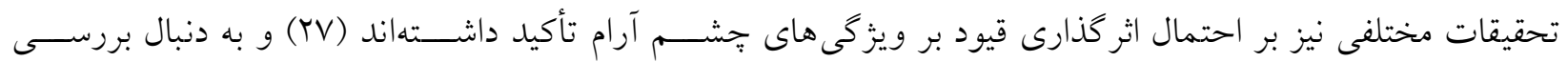

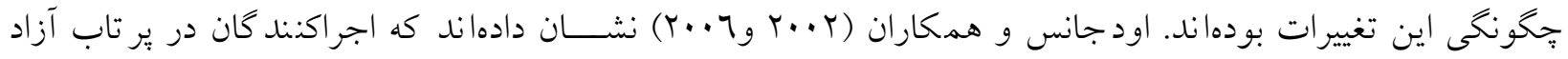
بـ سكتبال در شرايط مختلف محيطى ترجيح مى دهند كه از اطلاعات بـصرى متفاوتى براى هدايت عملكرد خود ا ستفاده

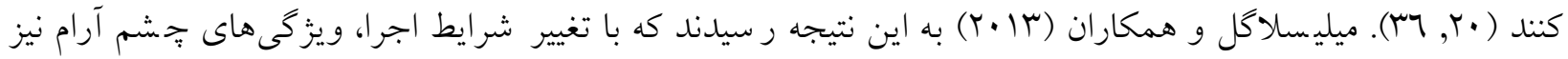
تغيير مى كند (1) (1). اين نتايج كه بر انعطاف يذيرى جششم آرام ذسبت به تغييرات محيطى تأكيد داشتند، با يزوهش حاضر همسـو هسـتند. همجنين يافتهاى يزوهش حاضـر مبنى براينكه اثر اصـلى بافت محيط به عنوان قيود محيطى بر تغيير

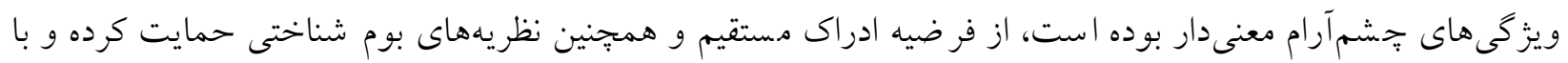

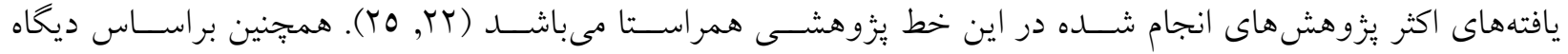

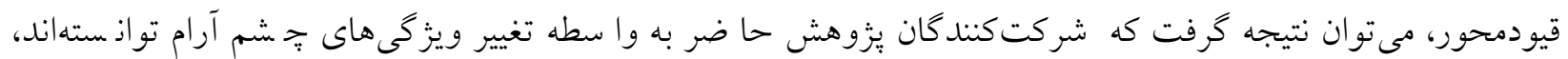
اطلاعات مورد نياز فراهم سازهاى محيطى را بخوبى كسب نمايند و به دنبال آن ويزگ هاى يوياى خود سازمانى حركت

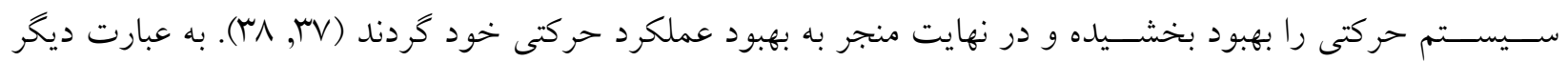
معطوف كردن توجه و جستجوى بينايى بر اثرات حركت در بافتهاى محيطى متغير، به واسطه جهت دادن به فرايندهاى جسـتجوى فراهمســازهاى مربوط به اجراى تكليف برتاب دارت، به اجر اكنندها در جسـتجو و كشـف اطلاعات ويزه محيطى مورد نياز جهت تو سعه جفت شدن ادراى و عمل و خودسازمانى قيود اجراى تكليف، جهت داده و به دنبال آن،

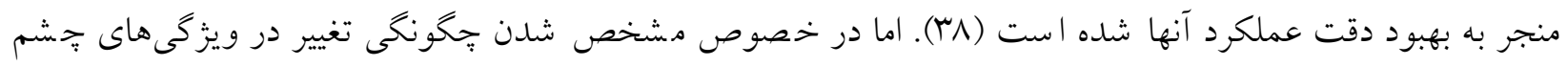
آرام طى اجرا در بافتهاى مختلف محيطى بايد كفت كه با افزايش بيجيد گیى تكليف كه به دنبال تغيير شرايط تنظيمى از حالت ثابت به حالت در حركت اتفاق مى افتل و همجنين تغييريذيرى بين كوشــشــى كه از حالت بدون تغييريذيرى به وضعيت با تغييريذيرى بين كوششى اتفاق مىافتد، مؤلفه آغاز جششم آرام افزايش مى يابد كه اين افزايش نشان دهنده نياز

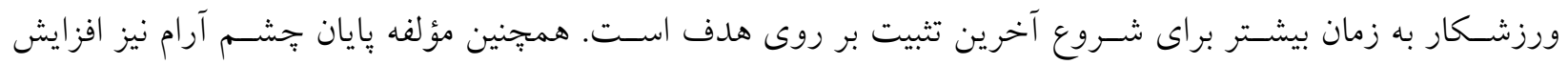




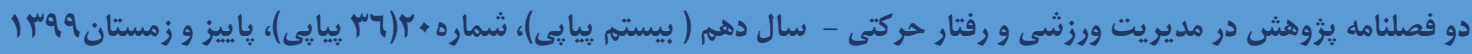

مى يابد كه اين افزايش نشان دهنده حفظ تثبيت طولانىتر روى هدف است به عبارتى ورشكار مدت زمان بيشترى روى

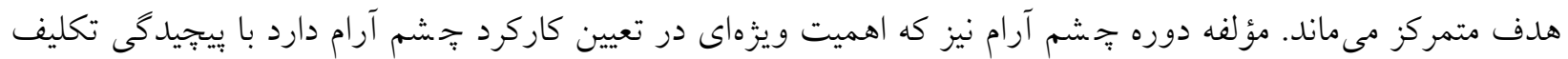
افزايش مى يابد، كه اين افزايش ذشان دهنده نياز به زمان بيشتر براى سازماندهى شبكههاى عصبى و پِارامتربندى بينايى است. باتوجه به اينكه در طول دوره جخشم آرام اطلاعات حسى مربوط به منطقة ظهور محرى و جهت حركت بردازش

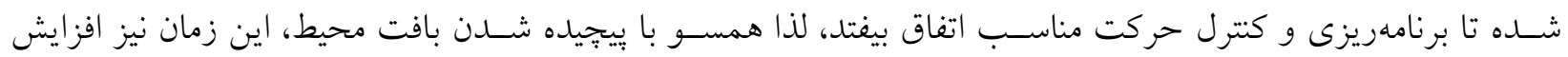
مىيابد تا با سخ حركتى مناسب اتخاذ شود. از آنجايى كه يِيجيدگى محيط موجب طولانىتر شدن مدت زمان لازم براى شنا سايى و تثبيت هدف شده است، حفظ اين تثبيت براى مدت بي شتر و جلو گيرى از انحراف زود هنخام آن مىتواند زمينه لازم براى يردازش، برنامهريزى و كنترل مطلوب حركت را فراهم آورد. اين بخش از نتايج با يافته هاى برخى از

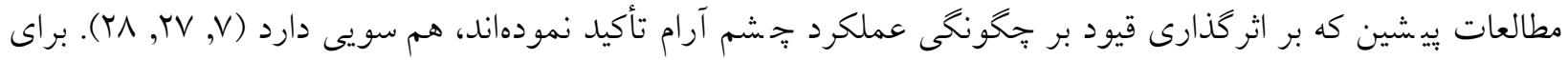

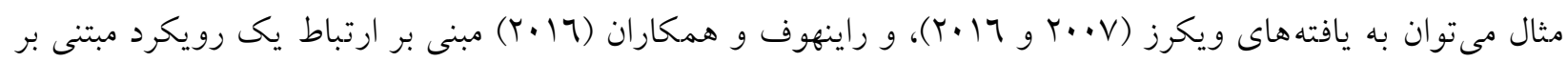

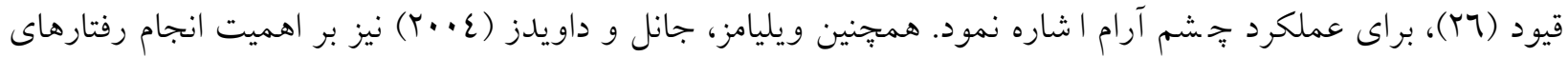

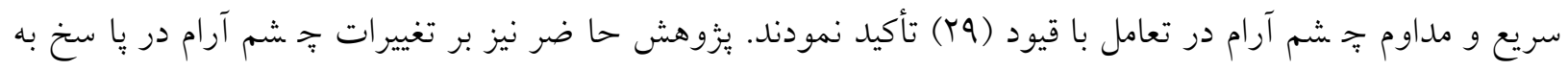
تغييرات بافت محيط در زمان اجرا اشاره نمود، بافت محيطى كه براى شركت كنندگان تاز كى داشت و مىتوان احتمال داد

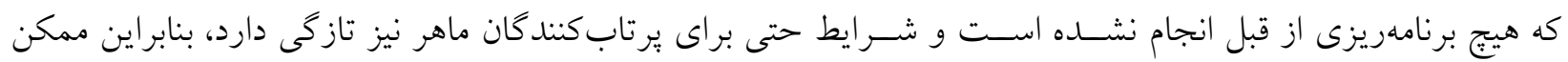

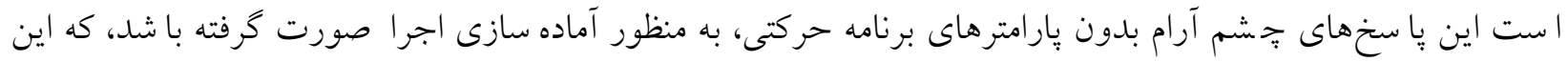

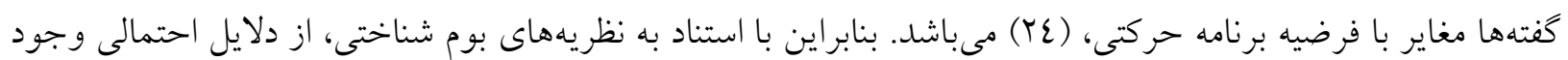

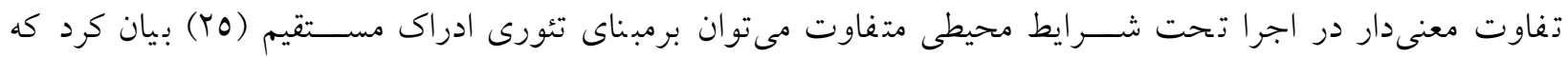
ويزّى هاى محيطى ممكن است يارامترهاى جشم آرام را براى اجراى تكاليف يرتاب، شكل داده باشند. حال با اســتناد بر اين مفاهيم مىتوان جنين برآورد نمود كه در شـــايط مختلف محيطى بخصــوص در موقعيتهاى

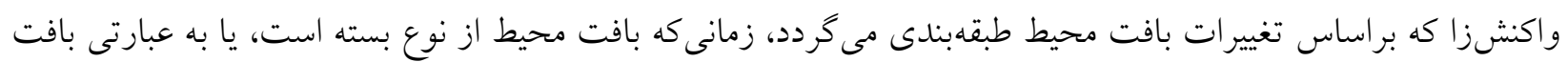

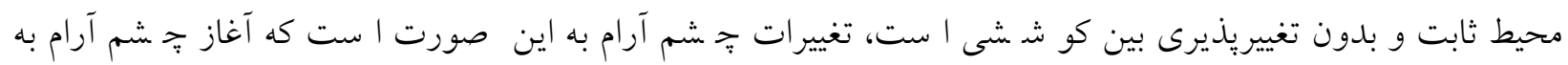

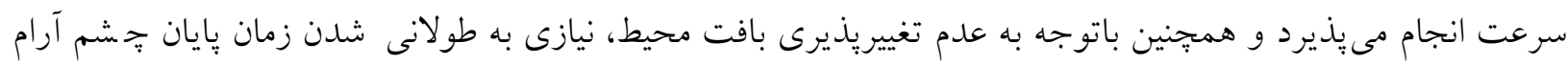
نبوده و ورزشكار مى تواند ياسخ خود را با سرعت بيشترى برنامهريزى نمايد. اما اين شرايط براى زمانى كه محيط از نوع

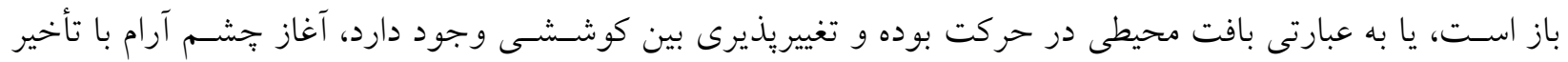
اتفاق مى افتد و براى كسب بهترين عملكرد ورز شكار به حداكثر زمان لازم جهت برنامهريزى و ايجاد يا سخ حركتى نياز

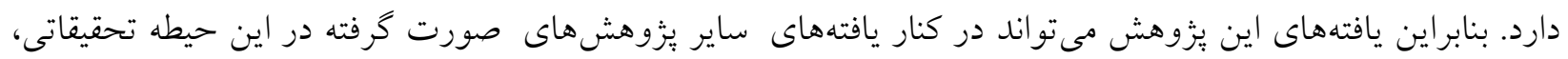
به مربيان و به طور كلى افرادى كه به نوعى با امر آموزش و ياد گيرى سروكار دارند، ييشنهاد كند كه با توجه به اثركذارى

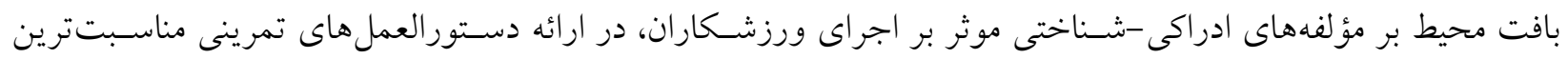


بافت محيطى را براساس تشابه شرايط تمرين و رقابت انتخاب نمايند (اصل اختصاصى بودن تمرين). از طرفى باتوجه به

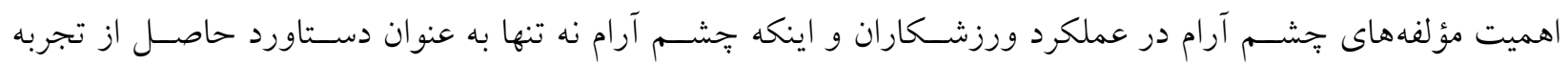
محسوب مى كردد، بلكه لازم است جهت د ستيابى به عملكرد ماهر انه آموزش داده شود (عال) بر آموزش اين مؤلفههاى

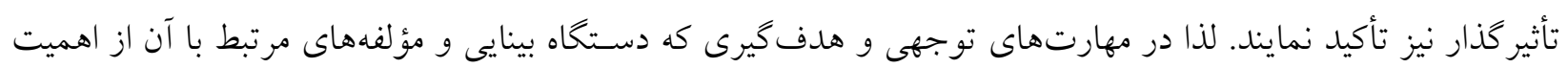

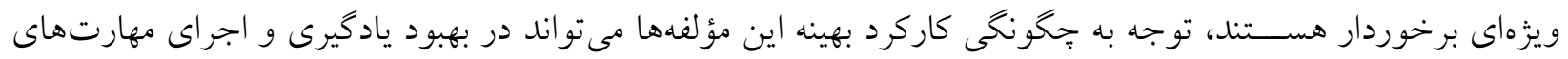
حركتى موثر واقع شود. تقدير و تشكر: اين مقاله بركرفته از ر ساله دكترى نويسنده اول و با نظارت و راهنمايى نويسنده دوم و سوم و مشاوره

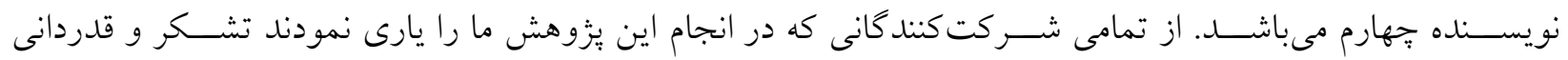

1. Konttinen N, Lyytinen H. Brain slow waves preceding time-locked visuo-motor performance. Journal of sports sciences. 1993;11(3):257-66.

2. Didier JJ, Li L, Magill RA. Environmental context affects outcome and kinematic changes at different rates during skill learning. Perceptual and motor skills. 2013;116(3):953-68.

3. Magill RA. Motor learning and control: Concepts and applications. 8 ed. USA. New York: Mc Grow Hill; 2011.

4. Gentile AM. A Working Model of Skill Acquisition with Application to Teaching. Quest. 1972;17(1):323.

5. GENTILE AM. Skill acquisition: action, movement, and neuromotor processes. 2nd ed ed: Movement science: foundations for physical therapy; 2000 Rockville. 111-87 p.

6. Edwards WH. Motor Learning and Control: From Theory to Practice (Available Titles CourseMate) 1st Edition ed. CourseMate AT, editor: Brooks Cole; 1 edition; 2011. 219-20 p.

7. Vickers JN. Perception, cognition, and decision training: The quiet eye in action: Human Kinetics; 2007.

8. Vickers JN. Mind over muscle: The role of gaze control, spatial cognition, and the quiet eye in motor expertise. Cognitive processing. 2011;12(3):219-22.

9. Amini A, Vaezmousavi M, Naji M. The Effect of quiet eye on the Performance of Shooting Arms. Tehran: Imam Hossein University; 2017.

10. Abernethy B, Wood JM. Do generalized visual training programmes for sport really work? An experimental investigation. Journal of sports sciences. 2001;19(3):203-22. 
11. Abernethy B, Maxwell JP, Jackson RC, Masters RSW. Skill in sport. In: Handbook of applied cognition. 2nd ed. New York: Wiley; 2007.

12. Tenenbaum G, Eklund RC. Handbook of Sport Psychology. 3rd Edition ed2007.

13. Williams AM, Ward P, Smeeton N. Perceptual and cognitive expertise in sport: Implications for skill acquisition and performance enhancement2004. 328-48 p.

14. Vine SJ, Moore LJ, Wilson MR. Quiet eye training: the acquisition, refinement and resilient performance of targeting skills. European journal of sport science. 2012;14 Suppl 1:S235-42.

15. Causer J, Janelle C, Vickers JN, Williams AM. Perceptual training: What can be trained? London: Routledge. 2012;1:306-24.

16. Wilson MR, Causer J, Vickers JN. Aiming for excellence: The quiet eye as a characteristic of expertise. New York: Routledge. 2015:22-37.

17. Foulsham T. Eye movements and their functions in everyday tasks. Eye (London, England). 2015;29(2):196-9.

18. Millslagle DG, Hines BB, Smith MS. Quiet eye gaze behavior of expert, and near-expert, baseball plate umpires. Perceptual and motor skills. 2013;116(1):69-77.

19. Moore LJ, Vine SJ, Cooke A, Ring C, Wilson MR. Quiet eye training expedites motor learning and aids performance under heightened anxiety: the roles of response programming and external attention. Psychophysiology. 2012;49(7):1005-15.

20. Oudejans R, Langenberg vdR, Hutter V. Aiming at a far target under different viewing conditions: Visual control in basketball jump shooting2002. 457-80 p.

21. Vickers JN, Lewinski W. Performing under pressure: gaze control, decision making and shooting performance of elite and rookie police officers. Human movement science. 2012;31(1):101-17.

22. Meijer O, Roth K. Complex movement behaviour: "The" motor-action controversy. Amsterdam: North-Holland; 1991.

23. Schmidt RA. A schema theory of discrete motor skill learning. Psychological review. 1975;82(4):22560 .

24. Williams AM, Singer RN, Frehlich SG. Quiet eye duration, expertise, and task complexity in near and far aiming tasks. Journal of motor behavior. 2002;34(2):197-207.

25. Piras A, Vickers JN. The effect of fixation transitions on quiet eye duration and performance in the soccer penalty kick: instep versus inside kicks. Cognitive processing. 2011;12(3):245-55.

26. Konttinen N, Lyytinen H, Era P. Brain Slow Potentials and Postural Sway Behavior During Sharpshooting Performance. Journal of motor behavior. 1999;31(1):11-20.

https://jrsm.khu.ac.ir/ 
27. Rienhoff R, Tirp J, Strauss B, Baker J, Schorer J. The 'Quiet Eye' and Motor Performance: A Systematic Review Based on Newell's Constraints-Led Model. Sports medicine (Auckland, NZ). 2016;46(4):589-603.

28. Vickers JN. Origins and current issues in Quiet Eye research. Current Issues in Sport Science. 2016;1(101).

29. Williams AM, Janelle CM, Davids K. Constraints on the search for visual information in sport. International Journal of Sport and Exercise Psychology. 2004;2(3):301-18.

30. Davids K, Araújo D. What could an ecological dynamics rationale offer Quiet Eye research? Comment on Vickers. Current Issues in Sport Science. 2016;1.

31. Vine SJ, Moore LJ, Wilson MR. Quiet eye training: the acquisition, refinement and resilient performance of targeting skills. European journal of sport science. 2014;14 Suppl 1:S235-42.

32. Wilson MR, Miles CA, Vine SJ, Vickers JN. Quiet eye distinguishes children of high and low motor coordination abilities. Medicine and science in sports and exercise. 2013;45(6):1144-51.

33. Alipor A. Search functionality and reliability Handedness Inventory Chapman Middle School Students. Journal of Iranian Psychologists. 2008;2(7):197-205.

34. Tabatabai. Esfahan: Islamic Azad University; 1392.

35. Ameri EA, Fahimi M. Children age 7 to 14 years living in motor function and vision. Tehran: University of Tehran; 1394.

36. de Oliveira RF, Oudejans RR, Beek PJ. Late information pick-up is preferred in basketball jump shooting. Journal of sports sciences. 2006;24(9):933-40.

37. Davids K. Increases in Jump-and-Reach Height through an External Focus of Attention: A Commentary. International Journal of Sports Science \& Coaching. 2007;2(3):285-8.

38. Davids K, Button C, Bennett S. Dynamics of skill acquisition: A constraints-led approach. Champaign, editor. Illinois: : Human Kinetics.; 2008. 